\title{
A mirror of society: a discourse analytic study of 15- to 16-year-old Swiss students' talk about environment and environmental protection
}

\author{
Albert Zeyer $\cdot$ Wolff-Michael Roth
}

Received: 4 March 2009/Accepted: 12 May 2009/Published online: 24 May 2009

(C) Springer Science+Business Media B.V. 2009

\begin{abstract}
Environment and environmental protection are on the forefront of political concerns globally. But how are the media and political discourses concerning these issues mirrored in the public more generally and in the discourses of school science students more specifically? In this study, we analyze the discourse mobilized in whole-class conversations of and interviews with 15- to 16-year-old Swiss junior high school students. We identify two core interpretive repertoires (each unfolding into two second-order repertoires) that turn out to be the building blocks of environmental discourse, which is characteristic not only of these students but also of Swiss society more generally. The analysis of our students' discourse demonstrates how their use of interpretive repertoires locks them in belief talk that they have no control over ecological issues, which can put them in the danger of falling prey to ecological passivity. As a consequence of our findings we suggest that teachers should be endorsed to interpret their teaching of environmental issues in terms of the enriching and enlarging of their students' interpretive repertoires.
\end{abstract}

Keywords Environment - Environmental protection - Interpretative repertoires ·

Discourse $\cdot$ Discourse analysis

Zusammenfassung Die vorliegende Studie berichtet über einen langen Forschungsweg, der damit begann, dass wir uns über die Resultate einer Umfrage bei 15 bis 16jährigen Schweizer Schülerinnen und Schülern zu Umwelt und Umweltschutz wunderten. In dieser Umfrage, die von Studierenden einer pädagogischen Hochschule durchgeführt worden waren, hatten die Schülerinnen und Schüler ein überaus positives Bild von ihrer Einstellung zu Umwelt und Umweltschutz gezeichnet. Wir beschlossen, dieses Resultat mit Klassen- und Tiefeninterviews genauer unter die Lupe zu nehmen. Drei Zentralschweizer Klassen der Sekundarstufe I wurden ausgewählt, weil sie sich im

\footnotetext{
A. Zeyer ( $\triangle)$

Institut für Gymnasial- und Berufspädagogik, Universität Zürich, Beckenhofstr. 31, 8006 Zürich, Switzerland

e-mail: albert.zeyer@igb.uzh.ch

W.-M. Roth

University of Victoria, MacLaurin Building A548, Victoria, BC V8W 3N4, Canada
} 
Vergleich zum Durchschnitt aller Klassen entweder besonders positiv oder relativ kritisch geäußert hatten, und weil sie je in einer (klein-)städtischen, ländlichen bzw. touristischen Region der Zentralschweiz zu Hause waren. Es wurden drei Klasseninterviews und zwölf Tiefeninterviews mit ausgewählten Schülerinnen und Schülern durchgeführt. Die Interviews wurden transkribiert und analysiert. Die Diskursanalyse ergab, dass sich der Diskurs der Schülerinnen und Schüler aus zwei elementaren interpretativen Repertoires aufbaute: dem Repertoire des „gesunden Menschenverstands” und dem Aktions-Repertoire (commonsense und agential repertoire). Beide realisieren sich wiederum in zwei Repertoires zweiten Grades. Das commonsense repertoire entfaltet sich in der dialektischen Spannung von ich|Ding zum Repertoire der Alltagswissenschaft (folk science) und in der dialektischen Spannung von ichldu zum Repertoire der Alltagspsychologie (folk psychology). Inhaltlich besetzten die Interviews Themen, welche durch folgende Titel umrissen werden können: (a) Konsum, Wirtschaftswachstum und Globalisierung als intrinsische Bestandteile eines zeitgemäßen Lebensstils, (b) Umweltschutz als gesellschaftliche Priorität, die in ihrer Wichtigkeit aber durch andere Themen wie Arbeitslosigkeit, Armut, Friede, etc. durchaus relativiert wird, (c) die Hilflosigkeit des Einzelnen in einer Welt voller ,anderer”, die sich aus verschiedensten Gründen nicht oder zu wenig um Umweltschutz kümmern, (d) Schutz der Umwelt nicht in erster Linie durch eine Veränderung der Einstellung, sondern mittels technischer/technologischer und institutioneller Lösungen, (e) eine kritische Beurteilung der Aktivitäten von Umweltaktivisten und Umweltorganisationen (Greenpeace, WWF) als unrealistisch, störend und den gesellschaftlichen Wohlstand gefährdend, (f) die Einschätzung von Frauen und politisch links stehende Menschen als umweltfreundlicher als Männer und politisch rechts stehende Menschen, und (g) die Preisgabe von Visionen einer umweltfreundlichen Welt zu Gunsten von pragmatischen Konzepten von Lebensqualität und Wohlstand. Dieses argumentative Feld deckt sich weitgehend mit einem Diskurs, der allgemein in der Schweizerischen Umweltdiskussion ausgemacht werden kann. Die Analyse zeigte, dass das Zusammenspiel der vier identifizierten interpretativen Repertoires nicht nur den Schülerdiskurs in den Interviews erklärte, sondern auf einer übergeordneten Ebene auch den aktuellen Umweltdiskurs, wie er sich heute in der Schweiz und wohl auch allgemein in vielen westlichen Gesellschaften präsentiert. Dadurch wurde auch die grundlegende Konstellation sichtbar, die den Umweltdiskurs durchdringt. Das Zusammenspiel der vier interpretativen Repertoires engt den für die im Diskurs eingelassenen Personen den wahrnehmbaren Handlungsspielraum nämlich so sehr ein, dass darüber der Glaube an die Selbst-Wirksamkeit des Einzelnen bezüglich Umwelt und Umweltschutz verloren geht. Als Konsequenz ergibt sich, dass die Lehrpersonen ihre Aufgabe in der Umweltbildung dahingehend interpretieren sollten, dass sie die Schülerinnen und Schüler dabei unterstützen, ihre Repertoires im Umweltdiskurs durch wissenschaftliche Repertoires zu erweitern und ergänzen, um sich damit die Sicht auf neue Handlungsspielräume zu erschließen.

Research in environmental education often investigates students' "beliefs" and "attitudes" towards environmental issues under the assumption that these are individual or personal characteristics. Underlying this practice is a focus on the individual as the basic unit of analysis. A different point of view is favored by discourse analysis, which orients to how talk, conversation, and other communicative processes are used to make meaning (Potter and Wetherell 1987). If one is to take this discursive approach, investigations change, for language and its expressive possibilities are then seen as inherently shared and a characteristic of culture rather than of individuals (Vološinov 1973). From this perspective, 
therefore, what students say and how they say it is analyzed as a reflection of the possibilities that language offers to its speakers rather than as a reflection of their subjectivities (Roth et al. 2008). Discourse is then considered to be an expressive machine that becomes "the primary object of research rather than [being seen] as a transparent representation of an individual's attitudes and beliefs or the true nature of events" (McKenzie 2003, p. 4).

In this study, we follow the suggestions outlined in a recent review article on the topic (e.g., Roth 2008) in taking such a discursive approach to talk about the environment and environmental protection as it is articulated in the discourse of 15- to 16-year-old Swiss junior high school students. Accordingly, if we write about attitudes and beliefs, we do not speak in terms of "things in the mind" or factors in the composition of people but in terms of forms of discourse that are part of the cultural and societal heritage that students acquire together with their culture and language (Edwards and Potter 1992).

We begin this article by providing a description of the cultural-historical contextincluding the Swiss environmental backdrop-within which our study is situated. We move to describing and exemplifying four stable discursive resources (i.e., interpretive repertoires) that students use to support more tentative and disputable statements and claims before presenting seven salient topics in the Swiss environmental discourse as they are reflected in the adolescents' talk. We conclude with the discussion of the salience of our results for the teaching of environmental issues in science education.

\section{Cultural-historical context of the study}

\section{Environment and environmental protection in Swiss consciousness}

Environment and environmental protection are important issues in Switzerland. More than two-thirds of Swiss people buy local products to protect the environment, more than half of them support fair trade and low energy products and avoid wrappings. More than $70 \%$ are ready to pay more for environmentally friendly products. This is what Swiss people answer when asked in a consumer survey ${ }^{1}$ about the environment and environmental protection. However, to capture a more differentiated picture of the situation, it is important to recall the changing nature of the position that the Swiss have taken with respect to the environment and environmental protection.

The Sorgenbarometer, the Swiss "barometer of worries," is a widely read instrument published by the Credit Suisse bank that has tracked the "state of concerns" of the Swiss people for over 30 years (Credit Suisse 2008). Politicians, schools, research, and marketing use it because it shows the issues that the Swiss consider the most important in, and to, their personal and societal life. It is surely one of the best instruments available to track changes in problematics that matter to the Swiss. Over the past 20 years, "environmental protection" has been one of the major concerns of the Swiss people. However, whilst in 1988 it was the most important societal issue for $74 \%$ of the Swiss, Fig. 1-our rendering of the results of the Sorgenbarometer-shows that during the following years a dramatic decrease has taken place by 2006 , when only $7 \%$ of Swiss people found environmental

\footnotetext{
${ }_{1}$ http://www.gs1.ch/Portals/0/2publish/001/0523/Page/einkaufsverhalten.pdf. A representative survey administered to 1001 Swiss consumers, by Accenture (a global management consulting, technology services, and outsourcing company registered in Hamilton, Bermuda) and GS1 Schweiz (the Swiss partner of GS1, a global organization dedicated to the design and implementation of global standards and solutions to improve the efficiency and visibility of supply and demand chains globally and across sectors).
} 


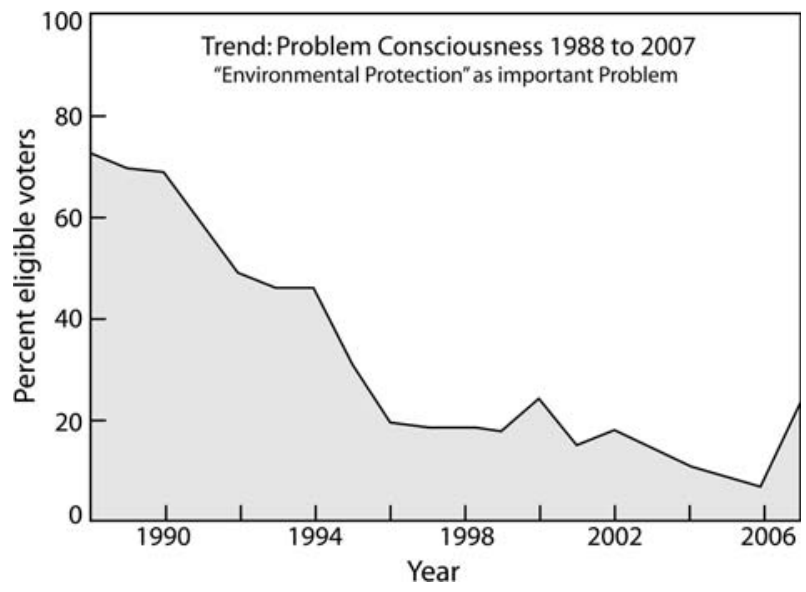

Fig. 1 The "barometer of worries" with respect to the importance of environmental protection presents the changing nature of Swiss concerns for environmental protection

protection to be the most important issue in their societal agenda. What happened during these 20 years that led to such a decrease in the social consciousness of Swiss people of an issue that now again attracts worldwide attention?

Obviously, other concerns had started to dominate the public discourse of the Swiss. In the already quoted survey Sorgenbarometer (barometer of worries), the Swiss provided the following list for the 2006 survey. The first three major concerns were unemployment $(66 \%)$, health and health costs $(55 \%)$, and rents $(51 \%)$. These three problems had constantly been on the first three places of major concerns during the last 6 years. Number 10 on the list was economic development (13\%). The environment no longer appears in this list of the top-ten worries. By 2006, the Swiss consider environmental problems to be important but much less important than many other problems. The list mirrors the societal worries of a nation that has been confronted (as many other countries) with decreased economic growth, increasing levels of unemployment, a new problem of poverty (especially of young single mothers), and societal restlessness in the context of social tensions, immigration, and financial problems in the national household. In this context, the salience of environmental problems to public discourses obviously diminished.

We ask what are the statistic facts about the environmental situation in Switzerland. The environmental report "Umwelt Schweiz 2007" (BAFU and BFS 2007) produced by the Swiss federal government sums up the state of affairs by stating that in the recent decade, the environmental situation of the country certainly has not improved. Though constant progress has been seen in concrete aspects like water quality, waste disposal, and certain aspects of air pollution, this progress-mostly realized by political measures and technological innovation-has been constantly undermined by the increasing environmental pressure caused by the Swiss way of life and consumerism. For example, the output of $\mathrm{CO}_{2}$ originating from traffic has been stabilized in the period since 2000. However, the private traffic volume has doubled since 1970 and the industrial traffic volume has tripled. The Swiss consume 2331 of water per person per day and produce $660 \mathrm{~kg}$ of waste per person per year. The consumption of end consumer energy rose $30 \%$ during the last 15 years and the gross domestic product also increased by more than 10\%. Since 1970, the average 
temperature in Switzerland rose about $1.5^{\circ}$. It is therefore not surprising that the report "Umwelt Schweiz 2007" provides a list of environmental challenges to the country including:

a. Climate change. Being a country in the Alps, the big mountain chain in Europe, Switzerland is much affected by the climate change and its consequences, such as glacier vanishing, inundations, and rock falls.

b. Biodiversity. Being a small country, the constant increase of traffic and the overdevelopment of vast areas of it, are a threat to biodiversity.

c. Health. Air pollution, noise, chemicals, extreme weather situations, and electromagnetic radiation are potential dangers to human health.

d. Innovation. New technologies can be a chance and a risk to the environmental situation.

e. Lack of an overarching environmental policy. The Swiss direct democracy and a marked regional diversity of the Swiss political landscape are a challenge to any coordinated management of environmental and natural resources.

The environment and the science curriculum in Central Switzerland

It is against this backdrop, that Switzerland makes considerable efforts to establish environmental education in schools. In Central Switzerland, an STSE curriculum for lower secondary level (grades 7-9) called "Lehrplan Naturlehre" (iEDK 1997) has been in use for more than a decade. Environment and environmental protection play a central role in this curriculum. This can already be seen in the preliminaries, where "acting responsibly in the environment and society" (p. 4) is one of the four explicitly formulated overarching goals of science education. The importance of treating the environment responsibly and caringly is highlighted. The teaching of environmental issues is expected to include the contradictory impact of science on the environment (e.g., the environmental destruction that comes with the production of required energy). Students should learn that science provides solutions for environmental problems but also constitutes an important source of them. The curriculum outlines that students will (a) acquire insight into environmental issues, (b) form personal positions on environmental topics, (c) become involved in local, national, and global environmental problems, (d) be ready to conserve the natural environment, (e) consume and live in an environmentally friendly manner, and (f) respect the environment during leisure and sports time. The approach taken by Swiss curriculum designers and educators thereby is comparable to the approaches in other European countries such as in France, where the curriculum emphasizes the so-called questions socialement vives (socially acute questions) (Simonneaux and Simonneaux 2009). Thus, in France, students reason about controversial socio-scientific issues including the reintroduction of bears in the Pyrenees in France, the protection of wolves in the Mercantour that have arrived from Italy, or global warming.

In Central Switzerland, the curriculum itself is divided into two parts. One part is dedicated to a disciplinary approach (biology, chemistry, physics), the other part to an integrated approach (science in context). The integrated part consists of eight application areas. Two of them are committed to environmental issues. The disciplinary part also includes many links to environmental topics. Subject areas that explicitly involve environmental topics include "our world we live in," "our world, a network system," "energy," "water as a basis of life," "green plants and their life," and "soil, basis of our food." 
When in 2003-2004 a new teacher education program for secondary teachers was started in Central Switzerland, a decision was made that this science curriculum should be the basis for the education of lower-secondary (middle school) science teachers. The new program situates teacher education at the tertiary level in the newly founded Pädagogische Hochschule Zentralschweiz (University of Teacher Education Central Switzerland). The new teacher education program had been designed from scratch to meet the standards set by the most up-to-date educational research. The teachers in training begin to teach from the onset of their studies. To that aim each teacher in training is assigned to particular classes, where s/he teaches in cooperation with the actual teachers. For certification, each teacher in training has to choose four subjects for his/her studies. The combinations are not delimited so that a teacher in training may, for example, become certified to teach German, mathematics, music, and science.

The emergence, evolution, and set up of this study

It was in these societal and educational contexts that the science education team of the new University of Teacher Education designed a new science teacher program in which the STSE curriculum was a central part. The research presented here step by step emerged from a task that we had given to the teachers in training. Consistent with current understanding in the field of science education, we wanted our teachers in training to connect with what students currently know. To sensitize the teachers in training to the forms of discourses students employ concerning the environment and environmental protection, we wanted them to find out what the students of the cooperating classes- "their" studentsthought about environmental issues and whether the curriculum had affected on their science classes in some way. The teachers in training took this task quite serious and collectively created a survey with three components: one for the students of the classes, one for their cooperating science teachers, and a guiding questionnaire for their own purposes to structure their observations.

The resulting survey was educationally motivated and, from a social scientific perspective, not without problems because, for example, there was no face validation or reliability established. Nevertheless, the three questionnaires contained interesting questions and they were administered to 47 of these cooperation classes and to their students (15-16 years of age). We helped our teacher students to statistically evaluate the data. The results of the survey were overwhelmingly "pro-environmental." For example, more than $90 \%$ of the students said that they found environmental issues important or even very important; and $62 \%$ asserted that they knew a lot about environmental issues. Half of the students $(50 \%)$ confirmed that environmental issues played an important role in their science class, $31 \%$ indicated that they would apply their environmental knowledge in school life and $40 \%$ agreed that they would apply it at home. A considerable $80 \%$ of the participants suggested that environmental issues were frequently or at least regularly on their mind.

The results showed furthermore that the STSE content of the science curriculum has had a considerable mediating effect not only on the teaching but also on the behavior of the cooperating teachers and generally on the school culture of the cooperating schools. The cooperating teachers asserted their serious engagement in environmental topics and more than $80 \%$ said that they felt that they were role models of environmental protection for their students. They said that they felt inspired by the content of the curriculum. The schools were sensitive to environmental issues in a considerable number of organizational and infrastructural aspects (Fig. 2). Waste separation was institutionalized in almost all 

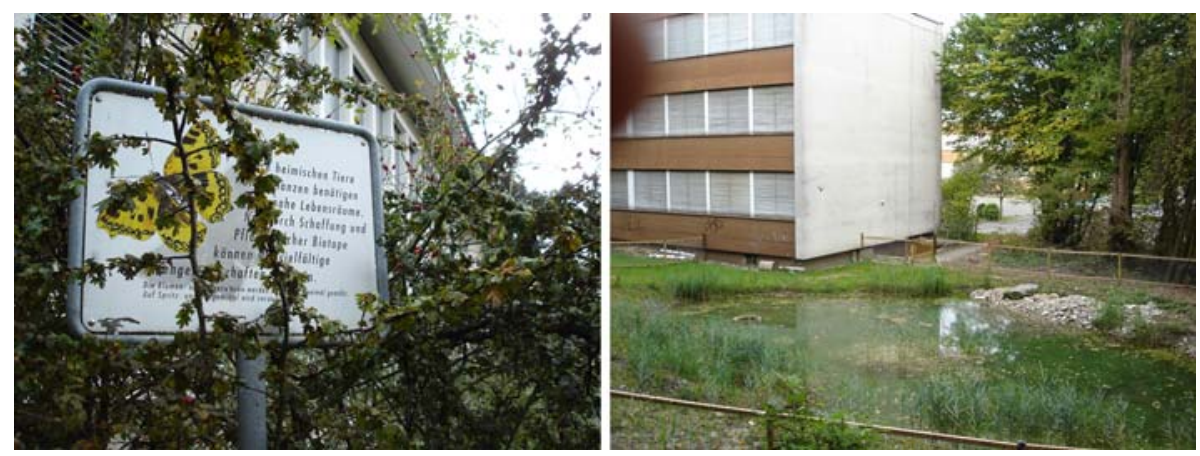

Fig. 2 The schools were sensitive to environmental issues. Left: A hedge of local plants in front of a school, marked by an explaining table. Right: A pond manufactured by science teachers and their students in a school project

cooperation schools. Many schools had implemented reasonable light and climate management and an outdoor area like a hedge (Fig. 2, left) or a pond (Fig. 2, right), where students could enjoy and study nature, fauna and flora.

We took the results with a grain of salt but found them interesting as expressions of the Swiss culture with respect to the environment. What did it mean that so many students found environmental topics "important"? How did they apply their knowledge in daily school life? What sort of "knowledge" was that anyway? Moreover, there were some results of that survey that seemed to trouble the general harmony in students' replies and to indicate some "hidden depths" in students' responses. For example, $42 \%$ of the students said that they found environmental topics in school science interesting, but $38 \%$ found them boring. Twenty percent said that treating these topics in school had no effect but $41 \%$ confirmed the phrase "we destroy our world" and the same percentage said yes to "if we all would join environmental protection, we could make it." We decided to conduct a study of Swiss environment-related discourses realized in conversations with 15- to 16-year-old students. We chose three classes out of the 47 that participated in the surveys. Two of them had provided above average positive answers to the survey, whereas one class had given below average responses on critical issues. One class was from an urban region, one from a rural region, and one from a tourist region of Central Switzerland.

In each of these three classes, we presented the results of the survey comparing their own means to those of the other 47 classes on six transparencies. To get an idea of how exactly we proceeded, consider Fig. 3. It is the reproduction of one of six individual transparencies that we presented to each of the interviewed classes. The figure presents the results to the question "What sentiments and emotions does the topic "environment" create in you?" The survey offered the participating students four statements concerning environment and environmental protection: (a) if all would join in, then we could make it; (b) these issues are frequently exaggerated; (c) in fact it doesn't matter to me; and (d) we destroy our world. The students were asked to indicate their approval or disapproval with each statement.

The reproduced transparency (Fig. 3) shows the results of one of these classes (red columns, right) and compares them with the average results of all other classes combined (blue columns, left). The graph shows that in the class for which this graph was generated,

${ }^{2}$ In Switzerland, the term ,Umwelt' (environment) is unambiguously understood in the context of ecology. 


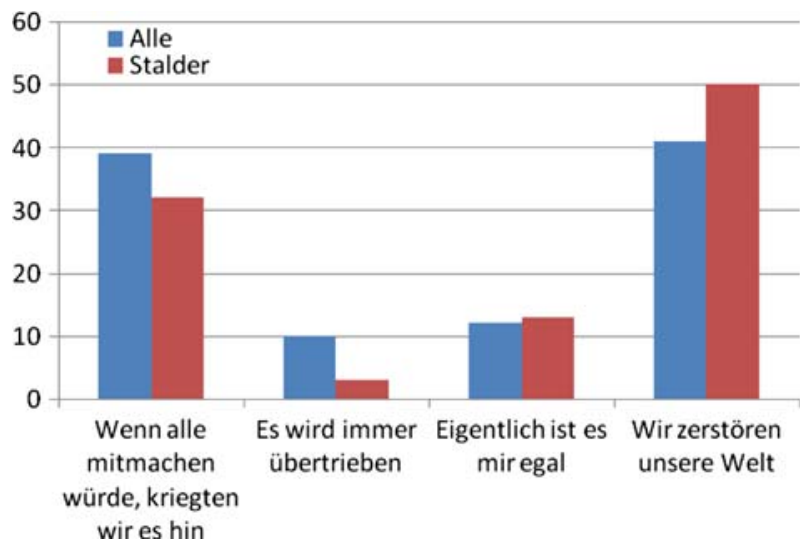

Fig. 3 Result of a questionnaire designed by pre-service science teachers ("What sentiments and emotions does the topic 'environment' ['Umwelt'] create in you?")

there was a more critical response than on the average of all other classes. On average, the students of this class scored lower on the question about the possibility that a collective joining of efforts would solve environmental problems. Considerably fewer students than in other classes agreed that the problems were exaggerated. The class did not differ significantly on the rejection of the statement that they did not care about environmental problems. A significantly higher proportion in this class than the average of the 47 other classes agreed that humans destroy their world.

Here, we are not interested in the results of the survey as such: constructed by students, it had not undergone validation. But we are interested in the ways in which junior high school students respond, individually in interviews and collectively in whole-class discussions, when confronted with the results that compared their average results to those of all other participating classes. That is, we are interested in the discourse mobilized by the students to explain, elaborate, and justify the results presented to them in the transparencies.

Data generation and interpretation

In this way, we used the results of the survey as topic and background for whole-class discussions. Each videotaped whole-class discussion lasted $\sim 45 \mathrm{~min}$. Based on an initial viewing of the tapes, we additionally chose 12 students for in-depth, videotaped interviews. We picked them because they gave interesting, largely consenting, or controversial answers during the class interviews. Two students were chosen because they were silent during the whole-class session. We also interviewed the teachers, using the same procedure as with their students. ${ }^{3}$

The whole-class discussions and the in-depth interviews yielded rich conversations led by Albert Zeyer. Our analysis shows that to realize particular positions with respect to the

\footnotetext{
3 The interviews were semi-structured. The questions were derived from the class-interviews. Additionally, the students were asked about their future job, about their attitude to school and about the environmental culture of their parents, siblings and friends. Each interview lasted about $30 \mathrm{~min}$, with a broad range of 20 min to almost an hour. Teachers were asked to comment on the initial survey, on the class-discussions (which they had assisted), and also on their reflections about teaching environmental topics in science.
} 
environment, our students always mobilized the same relatively internally consistent, bounded language units that their language and culture offers as a possibility. Such units have been called interpretive repertoires (Gilbert and Mulkay 1984). Interpretive repertoires have been used extensively in sociology and social psychology because they constitute something like a foundation in communication: "Repertoires could be seen as building blocks speakers use for constructing versions of actions, cognitive processes, and other phenomena. Any particular repertoire is constructed out of a restricted range of terms used in a specific stylistic and grammatical fashion" (Potter and Wetherell 1988, p. 171). These repertoires are clusters of collective, generally unquestioned discursive resources that speakers can employ to buttress a more tenuous claim. Thus, "while claims are tentative, interpretive repertoires are taken as unassailable statements in a particular discourse context," Roth and Lucas (1997) write, "which allows people to draw on these repertoires in support of their claims. Recent research in science studies and social psychology showed that individuals in all walks of life constitute and support the factual nature of statements, beliefs, attitudes, and epistemologies by means of such interpretive repertoires" (p. 145).

Our analyses show that throughout the whole-class discussions and the subsequent interviews, our students draw on specific interpretive repertoires. These repertoires therefore do not merely reflect individual students inclinations but they are in fact societally (culturally, linguistically) resources that students realize in a concrete manner because they can be taken as shared with all other members to the setting (Roth 2005). In drawing on these repertoires to address the researcher (Albert), our students in fact presuppose that he, too, draws on these repertoires to understand; and in not questioning the form or content of discourse that pertain to a specific repertoire, the researcher reifies its existence as a resource for all members of the culture.

We are quite aware of the fact that especially ethnomethodologists have questioned this repertoire-driven form of discourse analysis in arguing "that the in situ details of everyday life are ignored at the risk of reducing social life to recorded talk and conversational sequencing" (Holstein and Gubrium 2005, p. 488). However, we assume that the emphasis on the structure of talk itself can reveal the building blocks of our understanding how our students articulate their world, generally, and environmental situations, particularly. In so doing, we consider the students in our study to be (one) microcosm of (Swiss) society as a whole.

\section{Interpretive repertoires for articulating the environment and environmental protection}

Concerning the topic of environment and environmental protection, our analyses revealed the salience of two core repertoires and four-second-order repertoires. The analysis of the transcripts shows that in fact the Swiss environmental discourse, as realized here in and by means of students' talk, rides on the mobilization of these two/four interpretive repertoires. We called the two core repertoires the commonsense repertoire and the agential repertoire. Each of them splits up into two-second-order repertoires: the commonsense repertoire resolves into the folk science repertoire and the folk psychology repertoire whereas the agential repertoire divides into the pragmatist repertoire and the control repertoire. In the following, we describe and exemplify each of these two/four repertoires in detail. 
The commonsense repertoire

The commonsense repertoire reflects the argument that everyday knowledge falls into folk or commonsense theories. Here, "theory" does not mean "scientific theory." A commonsense or folk theory is theory-like insofar as it is resistant to counterevidence, committed to ontological beliefs, pays attention to domain-specific causal principles and is coherent in its construction of the outer world. The argumentation that ordinary knowledge can be linked to commonsense theories is rooted in a body of empirical research (Hirschfeld and Gelman 1994). People draw on the commonsense repertoire when it comes to the interpretation and classification of experiences. Similarity is then insufficient to solve the problem of classification or induction. People therefore need constraints on what counts as a feature and how to weigh these features in the conversation at hand. They find these constraints by drawing on the commonsense repertoire.

The relation to the outer world is framed in two dialectical tensions: melthing and melyou. Consequently the commonsense repertoire splits up into two partial repertoires: the folk science repertoire, and the folk psychology repertoire. Our students draw on both of these when interpreting the outer world.

\section{Folk science repertoire}

In mobilizing the folk science repertoire, students draw on observations that can be made in the everyday world, seen on television, or on topics that they know from science courses. The results of these observations are taken to be facts, etymologically (especially as factum in scholastic Latin) meaning things, events, or occurrences that have really and undeniably occurred and therefore constitute truths. This repertoire is akin to the perceptual repertoire-which invokes knowledge gained by interaction with the world-identified in previous research (Roth and Lucas 1997). However, we term this repertoire "folk science," because of its relation to objects (processes) and truth related to them. The students did not, as those in the Roth and Lucas study, make reference to the limitations of human perceptions, but took "facts" labeled by "scientific" - may they be conveyed by media or in science lessons - as absolute Truths. In taking scientific "facts" for granted the folk science repertoire is very close to scientism (Cobern and Loving 2007). The result is a mixture of personal observations, scientific "facts" known by authentic testimony rather than by inferences and synthetic judgments, linked together by "folk physical" argumentation. Consider the following fragment from one of the whole-class conversations.

1. Justin: Also ich überlege das schon gelegentlich, vor allem zum Beispiel im Zusammenhang mit dem Wetter. Bei solchen Extremwettersituationen kommt einem das schon etwas vor Augen, was man hätte machen sollen. Und man kann es ja immer noch machen. Dann wird einem das schon etwas klarer, und man hört es ja auch immer wieder im Fernsehen.

[i] Well sometimes I do reflect about that, especially in context of the weather. [ii] These situations, when the weather is so extreme, it shows you a bit, what one should have done. And one could do it yet, of course. [iii] That becomes clearer to you and you see it also frequently on TV.

2. Albert: Was heisst gelegentlich?

What does it mean, "sometimes"?

3. Nicole: Ich glaube, wenn man plötzlich merkt, dass die Situation eine andere ist, zum Beispiel im Zusammenhang mit den Hochwassern. Da begann ich plötzlich zu 
überlegen, ob es auch so weit gekommen wäre, wenn man sich etwas anders verhalten hätte.

[iv] I mean, when one suddenly realizes, that the situation is different, for example in context of the inundations. [v] Then I suddenly started to reflect, if it had also come this way, when we had acted differently.

In employing this repertoire, students create fixed points in their argumentation. In the above excerpt for example, Justin alludes to extreme weather situations that can be observed and experienced without scientific experimentation. The weather is something that can be observed everyday and in fact constitutes a common topic and beginning of conversation, especially among strangers. These observations are at a level of common sense so that questioning them would mean questioning common sense. However, Justin talks not only about the facts as such. He actually talks about his reflections ("sometimes I do reflect about that" [i]). Such self-evident observations may be used as evidence to support one's thinking ("These situations, when the weather is so extreme, it shows you a bit, what one should have done. And one could do it yet, of course" [ii]). However, this is only true if Justin and his listener take the scientific interpretation of these extreme weather situations as absolute Truth. Here, in using the definite article in the term "these situations," another student, Nicole, refers to the specific inundations that occurred during the time of the interviews and that therefore could be taken as a known referent for her remarks. The topic is salient in Swiss society where scientists and the media conceived this national catastrophe as a sign of global warming and conveyed that similar catastrophes would be more frequent in future. In the talk of Justin, this part of the interpretation is not made explicit. When he says that it "becomes clearer to you and you see it also frequently on TV" [iii] then he actually does not talk about the simple facts as such but about the facts interpreted by science. These interpretations are implicitly identified with facts, a typical fallacy of scientism.

Thus, after taking notice that the situation has changed ("one suddenly realizes, that the situation is different" [turn 3: iv]), evidence accumulates in the student's talk about what might have happened if one had acted differently ("Then I suddenly began to reflect..." [turn 3: v]). In both the premise and the consequent rethinking the adverb "suddenly" is mobilized, which dramatizes the sudden effect that the observation had on the subsequent thinking, as this is explicitly articulated in their talk. In parts of the turn, however, the role of scientific mediation is ignored. The simple fact is, that the situation is different from normal. Science says that the situation as such has changed and that acting differently could have had a different consequence. In the discourse, the causal relationship between the rainfalls and the global warming are taken as absolute Truth.

The folk psychology repertoire. The second repertoire emerging from the commonsense repertoire is created by the melyou tension. Our students draw on it to understand and predict the behavior of other persons as they interact with them. In such interaction, every member of society is a lay psychologist (sociologist) drawing on available linguistic and cultural resources that make something like a folk psychology: "Folk psychology involves our everyday understanding of how people work (how actions are caused by mental/ intentional states)" (Baron-Cohen et al. 1999, p. 2) By drawing on the folk psychology repertoire students use the commonsense theory of mind to construct the "you" and to predict his/her action.

The folk psychology repertoire that we identified in our database is similar to a repertoire that has already been described by previous research, the intuitive repertoire. "The intuitive repertoire invokes innate or instinctive knowledge, common sense, and 
personal or shared experiences" (Roth and Lucas 1997, p. 158). The folk psychology repertoire is closely related to the intuitive repertoire insofar as it is also grounded in intuition. The students refer to "what can directly be seen," i.e., to mind concepts that are so "by nature." It makes no sense to discuss the things, because you cannot change them. However, whereas the intuitive repertoire interprets both mental and physical states, our folk psychology repertoire is used exclusively to understand other minds. This restriction seems reasonable, because to understand things, our student predominantly draw on our first repertoire, the folk science repertoire, emerging of the tension melthing.

To illustrate the folk psychology repertoire, consider the following fragment from a class discussion in which a young woman articulates differences between women's and men's attitudes toward the environment.

Nora: Ich denke einfach, dass die Frauen das besser aufnehmen. Männer haben immer noch anderes im Kopf. Männer haben auch lieber Autos. Sie sind noch irgendwie eher auf dem spielerischen Weg. Wir Frauen wollen ja auch einmal fest eine Wohnung haben. Kinder und so, vielleicht nicht jede Frau, aber die meisten, und damit ist man auch auf eine Art gebunden. Die Hausfrau ist ja dann mehr zu Hause. Sie können Zeitung lesen und sind mehr damit konfrontiert als ein Mann, der jeden Tag um sieben Uhr arbeiten geht.

[i] I tend to think that women get that better. [ii] Men always have different things in their heads. [iii] Men also like cars. [iv] They somehow are on a more playful way. [v] We women want to have once a fixed home base, right. [vi] Children and so on, not every women, but most of them, and so one is bounded in one way. [vii] The housewife is also more at home, right. [viii] They can read the papers and are more confronted than a man, [ix] going to work every day at seven o'clock.

Nora suggests that women take social roles that differ from those that men take. Men are playful. They like cars and do not care so much about anything, whilst women want to settle down, have a house, children and be a housewife. The particle "ja" ("right," [v]), typical for Swiss German, signifies that consent is presupposed, that is, that the associated statement is common and shared. For example, the phrase "Wir Frauen wollen ja einmal" ("We women want to... right" [v]), the "ja" ("right") signals an understanding that all women eventually want the things or situation described, and that this is understood by the recipient(s), here the interviewer. In this particular case, the fact that women want their own home is taken to be true to such an extent that any listener simply will consent to it. The same would be the case for the statement "die Hausfrau ist ja mehr zu Hause" ("The housewife..., right" [vii]), the given fact, that housewives spend more time at their homes than men. The particle "ja" indicates a naturalistic stance: this fact is given "by nature." It is interesting that that the naturalistic framework provided by this young woman shows many traditional cultural traits. The wife stays at home and cares for the household and the man goes to work "everyday at seven o'clock" ([ix]). Things are "just like that." This, however, does not mean that the wife is uninformed about environmental aspects. On the contrary, because she can read newspapers at home, she is "more confronted" ([viii]). The "ja" also is a linguistic feature that points to the nature of this form of discourse as a repertoire, which can function as a repertoire only if it is (can be) taken as unquestionable. In the lifeworld of this young woman, itself a product of her experiences in the world, the role of women and the forms of experiences and access to the world is, as reinforced by the particle "ja" unquestionable. 
The agential repertoire

Our second core repertoire draws on the argument that things do not happen without actions and it is an acknowledgment of the human power to act (agency). This power to act allows human beings to act in and transform their social and natural worlds. It is therefore similar to the performative repertoire identified in previous research about high school students' career talk; this repertoire was defined as invoking actions and performances within science-related careers (Hsu et al. 2009). The agential repertoire differs from the performative, because it refers to the power to act rather than to the actions and performative dimensions as its derivative. The agential repertoire is used to link the obligation of an action to a human actor.

We encounter the agential repertoire in the following fragment where Albert, who moderates the whole-class conversation, had pointed out, that $50 \%$ of the students in this class had confirmed that humans destroy the world. It is Oliver who answers.

1. Oliver: Also ich finde, wir haben die Umwelt selber so gemacht wie sie jetzt ist. Wir sind eigentlich selber schuld. Wenn wir etwa noch etwas daran ändern wollen, dann müssen wir es selber machen. Wir können es niemandem in die Schuhe schieben.

[i] Well, I think it was us that have made the environment as it now is. [ii] It really is our own fault. [iii] If we want to change anything about it now, then we have to do it ourselves. We cannot blame anyone else for it.

2. Albert: Aber du würdest dich auch zu jenen zählen, die sagen, wenn wir das Richtige machen, kommt es schon recht heraus?

[iv] But would you count yourself among those who say that if we were to do the right thing, it would turn out well?

3. Oliver: Das kann ich nicht so sagen.

That I cannot say in this way.

Oliver elaborates that we (humans) created the present environmental situation ourselves ("it was us that have made the environment as it now is" (turn 1: [i]). He suggests that it is our fault and that we cannot blame someone else for it (turn 1: [ii]). If we wanted to change anything, then we had to do it ourselves (turn 1: [iii]). Albert follows up by asking Oliver whether he, however, would count himself among those that believe that we could have a positive impact (turn 2), to which Oliver responds that he cannot articulate the issue in the way proposed (turn 3).

Oliver thereby states that "it was us" that have made environment as it now is. And we, human beings, are, in this statement, capable of acting. This capability is such that it modifies the environment so that it becomes in the way it appears to young people today. The agency belongs to the community as a whole. Here Oliver explicitly links agency and responsibility in blaming ("fault") humans for the present state of the environment. Thus, no one else is to be (or can be) blamed for it. With Bakhtin (1993) we may say that there is no alibi in being: we are responsible for whatever we do even when we just sit and watch the world go by. That is, immediately associated with the concept of agency (power to act) is an ethico-moral dimension: every act is (can be) good or bad. In the foregoing fragment, Oliver articulates it to be bad ("fault") and, implicitly, also denotes the current state of the environment to be worse than desired. Albert articulates in the same fragment another side of agency, when he asks Oliver, if he would count himself among those who say that "if we were to do the right thing, it would turn out well." ([iv]) In this statement, agency is associated with positive values in that it is employed to "do the right thing." The agential repertoire as such is neutral from the standpoint of values because it only refers to the 
power to act but not to the effect that an action will have. If the result of the selected action is desirable, then action is deemed good and vice versa.

\section{The pragmatist repertoire}

The pragmatist repertoire emerges from the tension of the ideallreal dialectic with respect to the context. As in other dialectical terms and concepts, the pragmatic repertoire expresses itself differently when students consider some situation as part of the ideal world or as part of the real world. In the ideal world, one kind of action could be taken; but in the real world, full of contingencies, a different set of action is appropriate. Philosophers suggest that in this tension, "practical wisdom consists in inventing conduct that will best satisfy the exception required by solicitude, by betraying the rule to the smallest extent possible" (Ricœur 1992, p. 269). More often than not, however, everyday action contrasts the ideal (rule) and the real (solicitude) so that issues are placed into an either-or opposition. By drawing from this repertoire, students use realistic arguments often in opposite to ideal stances that could be taken (i.e., "in theory"). Thus, even if there might be some more preferable actions (in terms of environmental protection) in an ideal world, these may not be taken in the real world because in the given circumstances a worse action (in terms of environmental protection) may be required to reach desired objectives. For example, in the following fragment, the student begins by stating that the world is destroyed by consumption and consumerism. He then provides an example that driving cars is necessary, because there would be no work otherwise.

Fabian: Es ist sicher so, wir machen unsere Welt kaputt mit dem Konsum. Mit dem Autofahren usw. Aber es ist nötig. Sonst gibt es keine Arbeit mehr. Also wenn man zum Beispiel überhaupt kein Autofahren würde, dann gäbe es Probleme mit den Arbeitsplätzen. Dann könnte man nicht mehr arbeiten. Oder zum Beispiel ein Bauer, der Traktor fährt. Natürlich könnte man die Ränder von Hand mähen, wo man jetzt mit der Motorsäge hingeht. Aber es ist eine Frage der Bequemlichkeit. Und Kleider, jeder braucht Kleider. Kleider werden älter, werden gebraucht, kriegen Löcher.

It is for sure, that we destroy our world by our consumerism. With our driving of cars etc. But it is necessary. Otherwise there would be no more work. For example, if there were no more cars driving at all, there would be problems with the jobs. One couldn't work anymore. Or a farmer, who is driving a tractor. [i] Of course, you could cut the borders by hand, where at the moment you use a power saw. [ii] But it is a question of laziness/convenience. And clothes, everybody needs clothes. [iii] Clothes get older, are used, get holes.

In this case, there is a commonsense desirable goal (having work and jobs) in the real world, which confronts the desirable goals in an ideal world (protect environment). Drawing on the pragmatist repertoire means to develop an argument, what it means to reach goals in a real world and why-if you want to reach it-you cannot have "your head in the clouds" of an ideal world (you cannot stop driving cars if you want to keep jobs). Environment should be protected, but for economical reasons this cannot be done. The pragmatic repertoire often carries an ironic touch towards environmental attitudes that are depicted as belonging to an ideal world. The young man says, for example, "of course, you could cut the borders by hand" ([i]). But he does not consider this to be a reasonable proposition. Instead he demonstrates how ridiculous environmental desires can be. It is interesting to note that here the desirable goal belonging to the real world is "laziness/ convenience" ("But it is a question of laziness/convenience" [ii]). It is typical for the 
pragmatist repertoire to be employed against a normally highly valued goal of the ideal world (environmental protection) by a pragmatist, normally lower positioned goal of the real world (laziness/convenience). The same takes place, when the goal of an ideal world (environmental protection) is out ruled by a laconic everyday argument ("Clothes get older, are used, get holes" [iii]).

\section{The control repertoire}

The control repertoire sublates the opposition of self and other in a selflother dialectic with respect to agency. That is, in the same way as the pragmatist repertoire, the control repertoire harbors a tension, here between individual agency (self) and the agency of others. The control repertoire thematizes the relationship between what a single individual can do and does, on the one hand, and what the group/society s/he lives in can do and does, on the other hand. This relationship between the two forms of agency can be antagonistic, just as that between the ideal and the real. In this case, the locus of control lies outside of the specific individual. S/he cannot act in the way she would like to because the group as a whole is overpowering. In the following fragment, Albert directly enters into this topic by his question.

1. Albert: Kommen wir zu den Anstrengungen des Einzelnen

Let's talk about the efforts of a single person.

2. Michael: Sie sind nicht nutzlos, aber sie haben nicht so eine Chance wie in der Gruppe. Sie haben leider keine Chance.

They are not useless, but they don't stand a chance like in the group. These unfortunately don't stand a chance.

Here the researcher asks the young man how he feels about the efforts of a single person. The answer comes to the point only in the last phrase of the answer sequence, when the young man conveys that individuals "don't stand a chance." He draws on the antagonistic version of the control repertoire. It is interesting to note how he develops his antagonistic argument. He starts by saying, "sie sind nicht nutzlos" ("these ((the efforts)) are not useless"). The German word "nutzlos" semantically lies in English somewhere between "useless" and "senseless." So the young man first starts with a comforting phrase, which avoids completely devaluating the efforts of one single person. But then he confronts this single effort with the opportunities "of the group," and then the tension between self and other fuels the antagonistic dramatization. The locus of control lies outside of the self in "the others." This immediately leads to the final knock down: they "don't stand a chance" - which finally eliminates any hope for the power of a single person to bring about change. The self and the other appear in an antagonistic relationship.

It is typical for the antagonistic repertoire that the young man presupposes, that the "others" are in an antagonistic relationship to the single person. It could also be that "the group" would work with the same intention as the single person. But, as soon as "the others" enter the game, they are assumed to take an opposite stance to the single person, who therefore "stands no chance." This is so commonsensical, so much rooted in the repertoire itself, that it does not require explication. It is the tension itself, which brings by the antagonistic blocking between self and other.

The young man exhibits awareness of the severity of his judgment when he adds the qualifying adverb "unfortunately." With this adverb, he articulates being sorry to say what he says, because he knows that consequence of this judgment is considerable: There is 
actually no sense in taking singular efforts, in spite of how he had started his answer, namely with the remark "They are not useless."

Now consider another fragment. Albert talks to Tabea who decisively has made the point that the locus of control is inside the single individual. Albert follows to this argumentation and asks her again:

1. Albert: Dann hast du das Gefühl, dass es von den Einzelnen kommen muss?

[i] Then you feel that it must come from a single person?

2. Tabea: Es braucht den Anstoss, den Gedankenanstoss. Viele Leute haben darüber noch gar nicht nachgedacht. Sie haben auch in der Schule davon nichts gehört. Es muss ein Anstoss kommen, egal von wo. Umweltschutz ist Frage von uns allen. Wenn uns die Politiker das einfach sagen, und wir machen trotzdem nichts, dann nützt es ja auch nichts.

[ii] It needs the impact, the thinking input: [iii] Many people even don't have reflected about it. They also haven't heard about it in school so far. [iv] There must be an input, never mind where it comes from. [v] Environmental protection is the business of us all. [vi] If politicians say this, and if we do nothing, then there is no effect.

3. Albert: Also würdest du den Einzelnen eine Chance geben?

[vii] So you give a chance to a single person?

4. Tabea: Ja schon. Es muss einfach von irgendwoher ein Anstoss kommen, dass man überhaupt darüber nachdenkt.

[viii] Yes, I do. There must be the input from somebody that you think about it at all.

Albert asks the young woman, "it must come from a single person?" ([i]). "It" constitutes something like a starting point for an action. Tabea takes this up and answers, that it needs a "thinking input" (turn 2: [ii]). "Ein Anstoss" means in German "a kickoff, an impulse," and the discourse insinuates a mental input, because it supposes that "many people even don't have reflected about it" (turn 2: [iii]) The particle "it" points on environmental topics, and Tabea utters the speculation that people often do not give much thought to environmental problems, so therefore they need a "thinking impulse" that must come from somewhere. The tension between self and other is here conceived as synergistic. The group is fed, activated by the self, however, small and unimportant it may be. "Never mind where it comes from" (turn 2: [iv]), the young woman says, indicating, that it is not a special person needed to do it. Everybody could do it; s/he just has to make the first impact. However, Tabea suggests that "environmental protection is the business of us all" (turn 2: [v]). It is the community as a whole that has to fix environmental problems. "If oliticians say this, and if we do nothing, then there is no effect" (turn 2: [vi]), Tabea says. This does not express a synergistic connection between the talk of the politicians and the community. Therefore, the input must come from somebody else, "never mind where it comes from." Albert asks again, "So you give a chance to a single person?" (turn 3: vii] Tabea again confirms the synergistic connection between the self and the other, "Yes, I do" (turn 4: [viii]).

\section{Features of Swiss students' discourses about the environment}

Most science education research is concerned with scientific knowledge and conceptions as such without consideration of the concrete situations in which the knowledge and concepts might be useful. In contrast, discourse analytical studies explicitly focus on forms of language that are mobilized in concrete contexts and topics (Edwards and Potter 1992). 
In this study, therefore, we are interested in using the contextual approach of discourse analysis in investigating the deployment of interpretive repertoires in the central topics that the students addressed in their talk concerning the environment and environmental protection. In the foregoing section, we articulate two core interpretive repertoires, which split into four derivative interpretive repertoires. We find these repertoires sufficient to account for the discourse upon which to ground the more tentative claims students make about the environment and environmental protection. That is, these interpretive repertoires constitute the basic building blocks of the discourse. Based on the described interpretive repertoires we now present an analysis of the most salient topics concerning the environment and environmental protection that emerged in three class discussions and the twelve in-depth interviews. Our analysis is organized around seven core issues that we can find in our data sources. These issues, in the order of presentation, include (a) consumerism, economical grown, and globalization as causes of environmental degradation; (b) the importance of environmental protection; (c) the role of personal agency in a world populated with others who may not act likewise. (d) The search for solutions in technological progress rather than fundamental changes of attitude towards environmental issues; (e) the role of NGOs such as Greenpeace and WWF in bringing about changes; (f) the differences between men and women when it comes to thinking about and acting toward the environment; and ( $\mathrm{g}$ ) the visions of a future (of the) world. The participants can be seen to mobilize the two/four interpretive repertoires in various ways in support of their more tentative claims, statements, and positions. We view both the positions articulated and the repertoires mobilized in their support as societal resources characteristic not merely of the students but of Swiss society more broadly, which is the basic assumption of our type of discourse analysis. Paraphrasing Vygotsky (1986), we might say that practical consciousness for the environment, always and already mediated by language, is as much "consciousness-formyself" as it is "consciousness-for-others" (p. 256). We therefore constantly match the results of our analysis with appropriate aspects of the Swiss ecological backdrop developed in the introduction to this article. Notice that, whereas consciousness of and positions taken on the environment and environmental protection change over time, as seen in Fig. 1, repertoires may constitute much more stable characteristics of a cultural discourse.

Consumerism, economic growth, and globalization

Consumerism, economic growth, and globalization frequently are discussed in the media as causes of environmental degradation and global warming. In the first decade of the twentyfirst century, consumerism among young people is flagrant around the world as well as in Switzerland. For example, in Zurich-with one million inhabitants the biggest city in Switzerland-80,000 young adults (between 17- and 25-year-old) say that "partying" is their favorite leisure time activity. In Bern and Basel, the two next important Swiss German towns, 24,000 young adults say the same. In the summer season, Zurich hosted 94 parties in 7 days for young adults. Per year, Swiss young people on the average buy clothes for 1,000-5,000 Swiss francs. They like Prosecco and Champagne [Italian and French sparkling wines, respectively) and prefer stylish cosmetic tools, use anti-age day creams and go partying on holiday. This is what the most important consumer study in Switzerland found out. ${ }^{4}$ How about our students? How do teenaged Swiss today talk about consumerism? Here is a passage of an interview with a young man, Robin, wherein he talks about his attitude towards shopping.

4 11,000 interviews every second year, http://www.wemf.ch/de/print/machConsumer.php2007. 
1. Robin: Also wenn ich einkaufen gehe, dann überlege ich eigentlich nichts. Ich überlege nie, wie man das nachher verwerten könnte oder so, das kommt erst, wenn ich es nicht mehr brauchen kann.

Well, when I go shopping, I don't think about anything. I never consider how I could recycle it afterwards. This only happens when I want to get rid of the product.

2. Albert: Wenn es um das Reisen geht, auch in deiner Umgebung, wenn ihr Ferien plant, denkst du, dass ihr Umweltfragen berücksichtigt?

If you think about holidays, if you're planning to go on holiday, do you think that you consider environmental issues and questions?

3. Robin: Nein. Ich glaube nicht.

No, I don't think so.

4. Albert: Kleider kaufen?

And what about buying clothes?

5. Robin: Auch nicht.

No, I don't think so, either.

6. Albert: Wenn du deine Einstellung zum Kaufen allgemein charakterisieren müsstest? And if you had to generally describe your attitude towards shopping?

7. Robin: Es ist ok, es gehört heute einfach dazu.

[i] Shopping is okay. Today, it simply is a part of life.

During this entire interview fragment, the young man draws on the folk psychology repertoire. Robin speaks about things that "simply" (turn 7: [i]) are so and that do not need to be discussed. There is no link between environmental protection and planning holidays or buying clothing. The fragment ends with a strong demonstration of the finalizing power of the folk psychology repertoire: "Shopping is okay. Today, it simply is a part of life" (turn 7: [i]). There is no use discussing this point any further. Here we can see again an interesting aspect of the folk psychology repertoire. When students draw on it, they often talk in an impersonal manner. Robin does not say that shopping is okay particularly for him personally. He says that "it is okay" and that "it is" a part of life, which suggests that this is so for everybody. The particle "simple" underlines the common sense aspect of what he says. Shopping is a part of human life and as such there is no need for further explanation.

Generally, our students considered the economy in terms of personal goods and lifestyle and in the frame of their personal life as a resource of existence and of lifestyle. We asked them also to reflect on the economy on a larger scale, about globalization and progress in a general sense. Here is an excerpt from the interview with Martin.

1. Albert: Wie stehst du zu Globalisierung, zu Wirtschaftswachstum und so weiter? Ist das etwas Schlechtes? Ist es nötig?

What about globalization, economical growth, things like that? Is this bad? Is it necessary?

2. Martin: Ja, wenn wir jetzt sagen würden: Kinderstopp. Wenn keine Kinder mehr auf die Welt kommen würden, dann wäre es nicht nötig. Aber diese Kinder brauchen zu essen, sie brauchen Arbeit, die AHV muss bezahlt werden, deshalb braucht es Wachstum, Arbeitslosigkeit nützt nichts, wir brauchen einfach Arbeitsstellen. Es wäre schlecht für die Welt.

[i] Well, if we would say now: no more children... [ii] if we had no more children, then it would be unnecessary. However, these children need to eat, they need jobs, work, their rents will have to be paid, therefore growth is required. Unemployment is not good for anything, we need jobs, right. It would be bad for the world. 
3. Albert: Und was ist die Rolle der Einstellung?

[iii] And what about the attitude?

4. Martin: Klar braucht es eine andere Einstellung. Aber allein die Einstellung ist unnütz. Nur weil ich meinen Abfall trenne, Sonnenkollektoren auf dem Dach habe, das reicht nicht, wir brauchen Technik. Wir brauchen die Wirtschaft und wir brauchen das Geld vom Staat.

Okay, it needs another attitude. However, attitude alone is useless. [iv] Simply because I recycle my litter, because I have sun collectors on the roof, that's not enough. [v] We need technology. We need economy and we need money from the state.

Here the drawing on the pragmatist repertoire is again salient. Martin starts his answer with an ironic and ironizing proposal, "no more children" (turn 2: [i]). If we had no more children, then economical growth would not be necessary (turn 2: [ii]). Again he does not further discuss this proposal. This need is discarded by drawing on the folk psychology repertoire. There is no society that seriously would take into consideration to have no more children. This then is the starting point to construct again a tension between an ideal and a real world. If we decide to have children, then we enter into the real world, and there we have real needs like jobs, work, and rents. This is only granted by economical growth. If we no longer had children, then we would not be in need of economical strength, and then we could solve the problems of environmental protection by a change of attitude.

Albert's question "what about the attitude?" (turn 3: [iii]) can be heard as a weak protest against this eloquently presented chain of pragmatist arguments. In fact, the statement questions the inner logic of this argumentative chain. However, there is no mercy: "Simply because I recycle my litter, because I have sun collectors on the roof, that's not enough" (turn 4: [iv]), Martin says. The ironic touch is again a marker for the pragmatist repertoire to come: "We need technology. We need economy and we need money from the state" (turn 4: [v]). The description of a real world, where attitudes are okay, but not good enough!

Sometimes during the interviews, the ironic stance towards the attitude of an ideal world turned into rather aggressive complaints about people who had their heads "in the clouds." For example, the discussion in one class grew really hot when it came to the role of environmental organizations in politics and especially their protest against a new local supermarket. NGOs were accused of obstructing economical progress and of hindering the development of the countryside, especially when they impeded the construction of newly planned sport and leisure time arenas. At these occasions, the students criticized left-wing and Green politics as exaggerated, extremist, and destructive. Whenever they talked about these issues, students draw on the pragmatist repertoire to talk about what it means that they develop in an argument, what it means to reach goals in a real world and why-if you want to reach them-you cannot have "your head in the clouds" of an ideal world. The environment should be protected; but for economical reasons, this cannot be done. Political actors or institutions putting forward environmental issues are accused of violating the pragmatist repertoire. This demonstrates again an important aspect of the drawing on interpretive repertoires. People draw on them to mutually understand each other. If somebody appears to violate a discourse, then he causes irritation and negative emotions. In our interviews, this typically happened, when the students talked about "Green people." They rarely argued against their goals as such, against the importance of environmental protection as such. They only said that these goals are not reasonable in a real world, mostly because of economical reasons. The emotional coloring was mostly ironic or 
negative (aggressive) exhibiting students' irritation about the violation of the common, undisputed common sense articulated by means of the pragmatist repertoire.

With the pragmatist repertoire, one of our two variations of the agential repertoire, students use realistic arguments often in opposite to ideal stances that could be taken (i.e., "in theory"). Thus, even if there might be some more preferable actions (in terms of environmental protection) in an ideal world, these may not be taken in the real world because in the given circumstances a worse action (in terms of environmental protection) may be required to reach desired objectives. Here, in an ideal world people would spend their money on expensive environmentally friendly clothes. In a real world, however, people are ready to pay "horrendous prices" and prefer to buy brands and latest things with their money. Environmentally friendly clothes are also expensive-but they are not attractive for people ready to spend lots of money. In a real world, people pay high prices for a common desirable good, here brands and latest things, but not for an ideal goal, here environmentally friendly clothes. There is another pragmatist argument, why these young people would not buy environmentally friendly clothes: they are not easy available. "I've no clue at the moment where I could buy this kind of clothes," Tabea says once during her interview. In an ideal world, these young people would make an effort and try to find out, where they can buy these clothes. In a real world, however, the combination of high price and low availability is a reason for not buying them.

The unfavorable relation of price and performance as to environmentally friendly goods and actions was often at stake in these interviews. Students stated that they could not afford environmentally friendly clothes and that public transportation was often more expensive than private traffic. Organic labels, they said, were often more expensive without providing more quality than conventional labels. Therefore, it would be illusory to expect-especially from young people - to purchase these goods. Organic agronomy in general was criticized by saying that it was expensive and illusory, and public transports were articulated as being unable or unwilling to fully connect all parts of the country. Students articulated this position on environmentally friendly goods in terms of taken-for-granted discourse: In fact, in many shops, environmentally friendly goods are more expensive than other products. It is a common shared experience that can be made daily in the supermarket.

How important is environmental protection?

Environmental protection plays an important role in the public discourse of Switzerland. This issue is even more significant in education, where resonances are found not only in the current curricula, but also in teachers' engagement and in school culture and school infrastructure, where an environmental commitment plays an important role. The relevance of environmental protection to the current Swiss educational context is already figured in the fact that, for their survey, the pre-service teachers constructed the question "How important is environmental protection to you?" rather than other possible questions. That is, environmental protection as a topic is something entirely within the potentialities of current Swiss discourse (topics), and it does not astonish that many students responded to this question as being "very important." We showed this result to the students on one of our transparencies and asked them to comment it. Here is a fragment from one class discussion.

1. Albert: Die nächste Folie: Wie wichtig findest du Umweltschutz? Auffällig ist, dass viele von euch bei sehr wichtig sind. 
The next slide, how important do you find is environmental protection? It is salient that many of you are with "very important"...

2. Philipp: Es ist uns eigentlich wichtig, weil wir es behalten möchten, so wie es ist. Das Dumme daran ist nur, man müsste dann mehr auf das Auto verzichten. Das ist zwar wichtig, aber man macht es dann doch nicht.

[i] For us it is very important, because we would like to keep it as it is. The silly thing about is only, [ii] we then had to more give up car driving. [iii] This is important, [iv] but in the end one does not do it anyhow.

3. Albert: Du würdest also sagen, zwischen wichtig finden und etwas machen, ist dann noch ein grosser Weg?

[v] So you would say that between finding something important and doing it there is a long way to go?

4. Sophie: Für mich hat diese Antwort von uns sehr viel mit den anderen Antworten von uns zu tun. Wir sind überall über dem Durchschnitt. Das hängt sicher alles zusammen.

For me this has much to do with the rest of our answers. We are everywhere over the average. All fits together.

5. Albert: Was ist denn der gemeinsame Nenner?

What then is the common denominator?

6. Was steckt denn da irgendwo letzten Endes dahinter?

What lies behind all that?

7. Laura: Uns ist einfach wichtig was passiert, was mit der Umwelt, was mit der Klimaerwärmung im Moment passiert.

For us it is just important what happens to the environment, what happens with global warming this instant.

8. Linus: Mit den Abgasen und allem wird es auch wärmer, dann steigt das Meer und wichtige Meeresströmungen kehren um.

[vi] With the waste gases and all it gets warmer, the sea will rise and important sea currents turn their direction.

9. Albert: Ja genau, und jetzt kommt ja eben diese Argumentation: man möchte es gerne so behalten, wie es ist. Wie weit ist dann der Weg, um etwas zu machen?

Yes, and then comes the argument: we would like to keep it as it is, right? How far is it to get something done actually?

10. Linus: Es ist schon so, wir sind einfach zu bequem, um etwas zu machen.

[vii] That's how it is: we are too lazy to do something.

11. Philipp: Aber es ist nicht nur, ob wir interessiert sind in Umweltschutz. Es ist auch eine Frage von Zeit und Geld. Das ist nicht immer leicht.

But it is not only whether we are interested in environmental protection. [viii] It also is a matter of time and money. This is not always easy.

Albert explains that this slide depicts the results of the question "How important do you find is environmental protection?" He points out, that many of the students had answered that for them the issue is very important. The disputed question on the transparency asks how important environmental protection is to the students. In the presented fragment of a class discussion, the students confirm that they find this issue very important, and they point out that this cannot only be seen in their answer to this specific question, but in the overall picture of their answers. Environment is important to them, and they offer global warming as an example. Linus provides a scientific description of the causes ("waste gases") and the consequences ("the sea will rise" and "important sea currents turn their 
direction" [turn 8: vi]). In so doing, they draw on the folk science repertoire. In using the folk science repertoire, students draw on observations that can be made in the everyday world, seen on television, or on "facts" that they know from science courses and take for granted. Global warming is a topic that can frequently be heard and seen in the media, and also it was a theme in the science classroom, as the science teacher confirmed to us. The students take this information and the observations made in films and print media to be facts, meaning things, events, or occurrences that have really and undeniably occurred or will occur and therefore constitute Truths. Global warming is simply taken as a fact, and the turning of ocean currents will also be a fact. This must even not be discussed, because it is a part of reality. In fact, no other student in the class shows a reaction to this statement. It is simply accepted as common evidence.

The importance of environmental protection is grounded in these facts. Because global warming happens, because the turning of sea streams will occur, the students find it important to keep the environment as it is (turn 2: [i]). By saying "Yes, and then comes the argument" (turn 9), Albert also agrees with this common ground equally drawing on the folk science repertoire. At the same time, a second motive emerges: to keep the environment as it is one has to engage in certain actions. Here the students draw on the agential repertoire. This repertoire builds on the argument that things do not happen without actions. It is an acknowledgment of the human power to act (agency). This power to act allows human beings to act in and transform their social and natural worlds. If we want to keep the environment, we have to, for example, give up driving cars (turn 2: [ii]).

However, the students argue that this will not be done. Philipp says: "This is important (turn 2: [iii]), but in the end one does not do it anyhow" (turn 2: [iv]). Here he draws on the pragmatist repertoire, which mobilizes the tension that agency encounters when the ideal world comes into conflict with real-world constraints. In the present context, the ideal situation is to keep the environment in the state that it is. However, in the real world, this will not be done. Two reasons are given for that: (a) People are "too lazy" (turn 10: [vii]) and (b) "it also is a matter of time and money" (turn 11: [viii]). Both reasons are constraints in the real world and sufficiently explain why people will not take the ideal action (e.g., stop using cars).

In response to Linus, Albert rearticulates what he has heard the student say, "you would say that between finding something important and doing it there is a long way to go?" (turn 3: [vi]). In so doing, he uses precisely the structure that during our analyses we came to denote as pragmatist repertoire - the tension between doing something important and acting in a way that is realistic but ways away from that which should be done. This is consistent with the very idea of repertoires, which are something like containers of ways of talking available to anyone in the culture. And we draw on these repertoires whether we have a name for and can identify them or not. Thus, although the interviewer may not have been aware of drawing on what he now recognizes to be a repertoire, he has been mobilizing it in the same why that the students did. And both parties draw on the repertoire because they are speaking for others, expressing forms of consciousness that not only are characteristic of themselves but also the presupposed form of consciousness of the other. As both parties draw on the same repertoire, this implicit understanding is in fact reified.

Generally taken, when it comes to the importance of environmental issues, the combination of drawing on the folk science and on the pragmatist repertoire is quite typical for the argumentation pattern of these students. Drawing on the folk science repertoire, they speak about facts provided by the media, personal experience, and science education. The argumentation pattern goes like this: the facts about environment are bad therefore the environment should be protected. Here, the agential repertoire comes in. If something 
should happen, somebody must do it. Normally, in these argumentation patterns the agential repertoire unfolds in its pragmatist version. In an ideal world, certain measures of environmental protection would be taken. However, in a real world there a reasons why it cannot be done.

We saw two reasons students mobilized in their talk: (a) people are too lazy and (b) it is a question of time and money, that is, a question of economical concerns. There are, however, many other concerns that students put forward to argue why, in a real world, environmental protection cannot be realized as it should be done in an ideal world. Students provide other concerns like peace (meaning personal and social peace as well as a world in peace), racism, or immigration problems. Another important theme that often arises is poverty, something that bothers many of the students. These are precisely the same issues that emerge on the barometer of worries. The students therefore do not produce concerns which stand alone in the societal landscape, characteristic of a particular age section of society, but they use elements of the pragmatist repertoire that are common in Swiss society and frequently presented in Swiss politics and media as reasons for not acting ecologically. Our students demonstrate the underlying discourse mechanism: whenever they mention these concerns, which contend with the ecological concern, they draw on the pragmatist repertoire. In an ideal world, we could draw the consequences from available evidence. In the real world, however, there are many quite respectable reasons for not doing so.

Unemployment has been mentioned in this context rather infrequently. This is remarkable, because teachers asserted in the interviews their worries about the possible future unemployment of their students and that they therefore tend to neglect environmental topics in the classroom sometimes. Finally, it can be said that the importance of environmental protection rarely is disputed; it is grounded in the folk science repertoire and taken for granted. The "not acting" on the level of the agential repertoire is mediated by drawing on the two second-level repertoires, the pragmatist (you cannot do what you should in a real world) and the control repertoire (you can do what you should but it has no impact because "the others" are lazy).

\section{Personal agency and "the others"}

Agency has become one of the central concepts in the human sciences during the latter part of the twentieth century. In cultural sociology, for example, it is the dialectical complement to structures (Sewell 1992). Agency mobilizes structures and structures enable (constrain) agency. In their talk about the environment and environmental protection students mobilized the concept of agency and the (practical) constraints that mediated what could and could not be done. As with the psychological constructs, we are not interested here in imposing an external theoretical framework but in analyzing how our participants articulate different forms of agency with respect to the environment and environmental protection.

Agency was the topic when Albert discussed with the classes and individual students the question "Can we personally influence what happens to the environment?" Here is an interesting fragment of a class discussion concerning this concept. The class then discussed whether the local community, a tourist village at Lake Lucerne, should engage in environmental protection. Albert begins by posing a crucial question (turn 1).

1. Albert: Ich habe nur ein paar wenige Schüler erlebt, die überzeugt sagten, der Einzelne hätte eine Chance. Gibt es hier drin auch jemand, der das meint? 
[i] I've met only few students who convincingly said that the individual stood a chance. Is there anyone in this class who thinks like that, too?

2. David: Also der Einzelne, ich glaube, wenn ich etwas mache, und Sie etwas machen, und dann andere auch etwas machen, dann gibt es zusammen auch wieder viele. Besser als wenn ich denke, wenn ich es mache, dann bringt es nichts, also mache ich es lieber gar nicht.

Well, the individual person, I believe, [ii] if I do something and you do something, and then others also do something, as a consequence there are a lot of people together doing something. [iii] It's much better this way than to think if I do it, then it's of no use; [iv] so, I'd just better do nothing.

3. Albert: Da hat einer gestöhnt, warum stöhnte er? (Gelächter.)

There's someone moaning. Why is he moaning? (Laughter)

4. Zoe: Also ich glaube da nicht daran, ich meine, wenn die Mehrheit es nicht macht. (Zuckt die Schultern und macht eine Grimasse.)

[v] Well, I don't believe in it, I mean, the majority doesn't do anything. (Shrugs and grimaces)

5. Philipp: Also ich glaube, man muss ein wenig Werbung machen dafür.

[vi] Well, I believe we must promote it a little bit.

6. Chiara: Also für den einzelnen alleine gibt es nichts. Das nützt nichts.

[vii] Well, there's nothing to achieve for the individual. It doesn't help.

When Albert starts this fragment by asking whether "the individual stood a chance," he immediately starts by drawing on the agential repertoire. This repertoire draws on the argument that things do not happen without actions and it is an acknowledgment of the human power to act (agency). This power to act allows human beings to act in and transform their social and natural worlds. When Albert uses the term "to stand a chance" ("eine Chance haben") then he means "the power to act," "the power to transform the world towards an (environmentally seen) better place." By using the word "the individual," he activates the tension of the agential repertoire between the self and the other. The development of the discourse after his question shows how the tension between the agency of the self and the agency of others gives raise to the control repertoire. In this repertoire, speakers draw on the relationship between what a single individual does and can do and what the group/society s/he lives in does or can do. This relationship between the two forms of agency can be antagonistic. In this case, the locus of control is outside of the single individual. S/he cannot act in the way she would like to, because the group as a whole is overwhelmingly stronger. Zoe and Chiara draw on the antagonistic type of the control repertoire. Chiara says it bluntly: "There's nothing to achieve for the individual" (turn 6: [vii]), whereas Zoe gives the classical reason when drawing on the antagonistic control repertoire: “the majority doesn't do anything” (turn 4: [v]). It is interesting to see that also Albert and David draw on this form of the control repertoire. Albert does so when he starts his question by saying that he has met only few people who convincingly said that the individual stands a chance [i]; and David does so by pointing out that he finds that his way to see it is better than "to think if I do it, then it's of no use" (turn 2: [iii]). The intriguing point here is that both, Albert and David, draw from this repertoire and at the same time present contradictory statements. This is a salient illustration of a typical aspect of interpretive repertoires, namely that the same repertoire can be used to forward quite differing arguments. Remember that the repertoire is only a vehicle of the argument, the common ground of understanding. The argument itself may unfold by supporting this common ground, but as well by contrasting it. 
In fact the discourse of the entire fragment in fact shows different versions of the antagonistic control repertoire, either in form of statements or questions or denials. It is typical for the antagonistic repertoire that the "others" are in an antagonistic relationship to the single person. It could also be that "the group" works with the same intention as the single person. But, as soon as "the others" enter the game, they are assumed to take an opposite stance to the individual, who therefore "stands no chance." This seems to be so much common sense, so much rooted in the repertoire itself, that it does not require further explication (thereby treating it as a repertoire). It is the tension itself, which brings by the antagonistic blocking between self and other. In the presented fragment, the antagonistic control repertoire also follows this pattern. Albert links "the individual" with "no chance" and thereby mobilizes this repertoire in the same as Chiara. Zoe uses it in an indirect way by stating that she does not believe in David's version; and finally David points out a possible consequence of the antagonistic version of the control repertoire ("I'd just better do nothing," turn 2: [iv]). When drawing on the antagonistic version of the control repertoire, the locus of control lies outside of the individual.

The second version of the control repertoire is the synergetic version. Here the tension between self and other is conceived as building on and enhancing each other. The group is fed, activated by the self, however, small and unimportant this individual self may be. David draws on the synergetic version of the control repertoire. Here, the locus of control lies within the individual. David describes the mechanism of activation of "the others" in terms of a snowball effect: "if I do something and you do something, and then others also do something, as a consequence there are a lot of people together doing something" (turn 2: [ii]). It is quite typical that David uses a personalized form by talking about "me" and "you." He starts by talking about "the individual," that is, to make a general statement, to hesitate, and to continue in this personalized form. The locus of control lies within himself, and he affects "you," meaning Albert, or somebody else by passing over the locus of control to him, and so on.

Philipp also draws on the synergetic version of the control repertoire; and he also uses the personalized talk: "we must promote it a little bit" (turn 5: [vi]). The fragment exhibits an important mechanism of the two different forms of the control repertoire. The synergetic form presupposes the locus of control inside the individual and provides an active form of talk about action. The antagonistic form presupposes the locus of control in "the others" and provides passive form of talk about action.

As in this fragment, both versions of the control repertoire are frequently found in the interviews. However, the antagonistic version is more frequent and it is often combined with the pragmatist version of the agential repertoire. Students tend to say that in an ideal world an individual could be successful in activating "the others" but not so in the real world. In the real world, "the others" often do not use their power to act, because they do not realize what should be done, or they do not want to do it, or they are too late to do what should be done. "The others" are often part of "the industry" that dodges environmental laws and indeed conspires against environmental progress. The motorcar lobby, for example, is suspected of systematically blocking the development of pollution-free car engines. Accusations like that are never concretized; they always depict a mystifying, fiction-like portrayal of the evil.

"The others", however, can be much bigger than only one branch of industry. Other countries can represent them, for example. Many students articulate the "other" when they talk about bigger countries that are less concerned about the environment than their own country. Since Switzerland is small, students articulate the suspicion that its political efforts are compromised by international carelessness. Most frequently "the others" are the 
United States. In many students' discourse, the US appears as a symbol of an overwhelming power factor against environmental concerns that shrinks individual commitment to sheer helplessness.

Better technical progress than a change of attitude

The agential repertoire, drawing on the argument that things do not happen without actions, is an acknowledgment of the human power to act. It draws its differentiation from the tension between an ideal world and a real world, respectively, between the self and the other into two-second-order repertoires (the pragmatist vs. the control repertoire). Technical progress seems to respond to both repertoires because in it the power to act is projected into nonhuman procedures that seem to mediate between the ideal and the real world, on the one hand, and between the self and the other, on the other hand. No wonder students often talk about solutions coming from technical progress. Here is a fragment of an interview with a young woman (Aline), who speaks in a typical way about technical progress.

1. Albert: Es gibt Leute, die sagen, wir brauchen eine andere Einstellung. Andere sagen, wir schaffen das mit der Technik.

There are people who say that we need another attitude. Others say we shall make it with the help of technology.

2. Aline: Ja sicher, es braucht Lösungen.

[i] Yes, sure, solutions are needed.

3. Albert: Du bist nicht jemand, der sagt, es müsste eigentlich alles ganz anders laufen?

[ii] You aren't someone who says that we should do it quite in a different way?

4. Aline: Nein. Das nicht.

[iii] No. This not.

5. Albert: Dann traust du der Technologie relativ viel zu?

Then you have a lot of trust in technology?

6. Aline: Ja, ich finde das gut.

[iv] Yes, I think this is good.

This discourse draws on the agential repertoire in its core form. This repertoire draws on the argument that things do not happen without actions and it is an acknowledgment of the human power to act (agency). This power to act allows human beings to act in and transform their social and natural worlds. If something should be done, then an action by somebody has to be involved. Albert proposes two ways of acting: one is changing the collective attitude and the other is using technology. The discourse gives this proposition an unexpected interpretation. Aline says, "Yes, sure, solutions are needed" (turn 2: [i]). On face value, this is not a decision for one of the two offered ways. Albert, however, responds by saying "(so) You aren't someone who says that we should do it quite in a different way" (turn 3: [ii]). This turn interprets Aline's answer as a statement in favor of the technology. Aline's "No. This not" (turn 4: [iii]) confirms this interpretation. The discourse constructs "technology" as "providing solutions" and-as the other side of the same coin - the change of attitude as a way of "no solution." Technology is seen as a way of acting, of having a real impact on a real situation. A change of lifestyle ("es müsste anders laufen") is not articulated as a solution, as a way to act and to transform the social and natural worlds. Aline has confidence in technology ("traut der Technologie zu"), that is, articulates the potential in technology to solve environmental problems. This power to act, she finds "is good" (turn 6: [iv]). 
Overall, to protect the environment the students tend to trust technical and technological solutions more than behavioral changes. They credit science and technology with providing solutions since they do not attribute political power to the public consent and feel overwhelmed by the negative influence of "the others." The examples they give in the discussion, however, are rudimentary and imprecise from a scientific and technological perspective. They know that some hydrogen technology is on the way, but they do not describe in more detail what it is. They also articulate that there are some potentialities in innovations like fuel cells and solar panels. Many of the students talk about these innovative technologies as having been suppressed by conspiracies of "the others," which in this case means people of the energy lobby and of the automobile industry, and that innovative technologies would be much more successful without these negative influences. Here again, they draw on the antagonistic version of the control repertoire. "The others" appear in a perspective of conspiracy against progress. They normally do not have an appropriate scientific background to understand the underlying technical problems. There was only one young man, a future mechanic of motorbikes, who really spoke with expertise. Even he, however, did not give much credit to new energy sources and engines. He found that they were too expensive and not developed enough.

In sum, only a few statements use the agential repertoire to acknowledge that behavioral change could be more important than technological progress. All other statements are in favor of technological solutions. No student entirely exhibits disdain for the potentialities of future technology for environment. Technology appears as materialization of agency, as the materialization of the power to act.

\section{The crazy people of Greenpeace and WWF}

Our students were rather sceptical towards Non Governmental Organisations including World Wildlife Fund (WWF) and Greenpeace. They exhibited respect for the political intentions of these organizations and their role in modern society. However, did not talk with admiration about environmental activists as modern heroes but suspected them to be idealistic troublemakers that do not take notice of societal realities. Consider a fragment of an interview with a student whom Albert asks about his thoughts concerning these organizations.

1. Albert: Letzte Frage: WWF und Greenpeace. Was hältst du von solchen Organisationen?

One last question: WWF and Greenpeace. What do you think of organizations like these?

2. Martin: An sich die Idee ist super, ist genial. Man hilft Leuten, man hilft der Umwelt. Die Frage ist einfach, wenn man da Geld gibt: Wohin geht das Geld, wer hat dieses Geld? Wird das Geld, das ich gespendet habe, wirklich eingesetzt dafür, was die mir gesagt haben? WWF und Greenpeace sind relativ bekannt und kontrolliert, dort habe ich das Gefühl, dass man vertrauen kann. Bei kleineren Dingen weiss man aber nicht, ob das Geld wirklich am richtigen Ort verwenden wird, oder in einen privaten Sack hineinläuft.

[i] The idea as such is great, is ingenious. One helps people, one helps the environment. The question simply is if one gives money where the money goes to and who has received it? Will the money, which I've given, really be used for the things that I was told? [ii] WWF and Greenpeace are relatively famous and controlled. As to these two organizations I've got the feeling that people can trust in them. [iii] Speaking 
of smaller institutions, one doesn't know if the money is really used at the right place or if it ends up in someone's private pockets.

3. Albert: Was sagst du zu den Aktionen als solches? Strassen blockieren, etc.? [iv] What do you think of actions like blocking streets and things like that?

4. Martin: „Das esch en Seich”, streiken bringt jetzt in jedem Fall nicht viel. Es geschieht eh nichts, ausser dass es Krach gibt. Besser vernünftig zusammen gehen und mit den Leuten reden.

[v] That's bullshit. At any rate it makes no sense to strike. Anyway nothing happens except of a lot of trouble. It's better to reasonably go together and speak to each other.

5. Albert: Eine Fabrik entern und ein Plakat an den Schornstein hängen?

To enter a factory and put up a poster on the chimney?

6. Martin: Ja, kann man machen.

Yes, one can do this.

7. Albert: Aber du denkst, das nütze nicht so viel?

But you think this isn't of much use?

8. Martin: Also wenn man zum Beispiel Lastwagenblockaden macht, das geht nicht. Man schadet mehr, als dass man nützt. Ich finde Aktionen gut, solange sie nicht irgendwelche Arbeiten oder Leute blockieren, weil sonst bringt es nichts. Die Leute werden hässig und man hat nur noch Stress mit ihnen.

Well, if you block, for instance, lorries, it doesn't work. You do more harm than useful things. I think actions are good, as long as they don't disturb any work or people, because otherwise it it's no good. [vi] People get angry and then these (activist) people merely get on your nerves.

When Martin says, that he finds "the idea as such great, is ingenious" (turn 2: [i]), he already draws on the pragmatist repertoire. In the term "ideal" we find the counterpart of the "real," the world seen through a pragmatic lens. He provides a "real" reason for why in a real world this ingenious idea is not practicable. He does so by describing that one never knows if the money does not end "in someone's private pockets" (turn 2: [iii]). Drawing on the pragmatist repertoire here means this: in an ideal world, the NGOs would save the world with the help of the money we give to them. In a real world, however, many of these organizations misuse the given money for private goals. It is typical for the pragmatist repertoire to build a tension between highly valued societal goals (give money for promoting ideal stances like environmental protection) and pragmatic considerations paying attention to real-world considerations (given money tends to end in private pockets). According to this attitude it is not the trust in peoples' integrity that is reassuring but the fact, that WWF and Greenpeace are "famous and controlled" (turn 2: [ii]).

When Albert invokes "blocking streets and things like that" (turn 3: iv], alluding to strategies especially of Greenpeace, Martin produces a strong vernacular refusal ("that's bullshit" turn 4: [v]). In the database, we frequently observe such emotional reactions on the parts of individual interviewees and even whole classes when the talk concerns a person or group who violates the rules underlying an interpretive repertoire.

The next turns between Albert and Martin (turns 5-8) explicitly draw on the pragmatist repertoire: The idea as such is ingenious (turn 2: [i]) but the means to accomplish it are unrealistic, producing only trouble and hurting the realist conditions of economy. It is interesting to see that Martin not only reacts harshly on a personal level but also similarly conceives the public reaction. People get angry, he describes the reaction of "everybody" and Greenpeace activists "merely get on your nerves" (turn 8: [vi]). 
During the interviews, WWF had a better reputation than Greenpeace. Yet this judgement was not based on profound knowledge about these two organizations. Only one student had been studying the web pages of Greenpeace and WWF and was in a position to argue about them with greater depth. His claims, however, did not differ from that of the other students. All of them expressed dislike for the public actions of Greenpeace. They found that its actions were destructive and overdone. Students said that it was not useful to provoke other people and to disturb their daily lives. They especially abhorred the obstruction of economical processes, the typical pattern when drawing on the pragmatist repertoire. Actions like the capering of ships or the blocking of truck traffic were completely articulated as being inexcusable. Students described such interventions as counterproductive, tasteless, and even childish. What strikes us here is the emotional distance to, and the complete lack of identification of these youths with, the activists of Greenpeace and other NGOs.

Why women make better environmentalists

A favorite comparative dimension in educational research is that articulating gender differences. In a discursive approach, the question of gender is only relevant in as far as participants themselves mobilize gender differences to make or support claims (Hsu and Roth 2009). Thus, in this research we are not interested in gender differences other than those that the participants themselves articulated as part of their talk about environment and environmental protection. The discursive repertoires we identify here are not only building blocks of the students' conversations, but they are also used to construct gender differences with respect to the environment, especially in the context of shopping.

The tension between high prices of environmentally friendly goods and the readiness of people to buy them-one example of the pragmatist repertoire that we identified in our students' talk — can also be found in public discourse. A representative consumer survey of Swiss people in 2007 precisely draws on this repertoire when asking what is important for consumers when they shop. Among other aspects, like "fresh goods" or "availability," they also offer a "good price" and are "environmentally friendly." One interesting result is, that men and women react differently to this item. Nearly $53 \%$ of women chose "environmentally friendly" as one of their top five criteria for the food choices they made, whereas "good price" did not appear as one of the five most important features for women. In contrast, $38 \%$ of men favor lower costs. That the purchased goods are environmentally friendly is none of the five most important concerns for male respondents.

The results of a survey can be taken as a picture of "reality" through the lens of the instrument. However, we prefer looking at them as a source of interpretive repertoires. Here, we may read the survey results as drawing on the folk psychology repertoire. When these women and men ask the questionnaire, the hidden rule could be, that women are "by nature" environmentally conscious whilst men are not. If this was so, we should find similar patterns in the discourse of our students. Consider the following fragment:

1. Philipp: Also ich würde auch gerne einmal mit dem Auto einfach herumfahren.

Well, I myself would also once prefer to just sit into a car and drive around.

2. Mara: Ich glaube, das ist in den meisten Situationen so, dass Mädchen und Knaben diesbezüglich getrennt sind. Es gibt aber sicher auch Mädchen, die sich überhaupt nicht interessieren. Und dafür Knaben, die sich eher mehr interessieren, aber wahrscheinlich sind sie eher in der Minderzahl. 
I believe, in most of these situations, boys and girls are separated. Surely there are also girls who are completely disinterested. And on the other hand boys who are rather more interested, however, usually they are rather a minority.

3. Albert: Hast du auch eine Idee, woher das kommen könnte?

Do you have an idea where this does come from?

4. Mara: Ja, ich denke, es ist den Knaben vielleicht nicht so wichtig. Sie haben dafür anderes, was den Mädchen nicht so wichtig ist.

Well, I think perhaps it is not so important for boys. Likewise they have other things which are not so important for girls.

5. Albert: Was denn so?

Could you give an example?

6. Mara: (Lacht.) Ja dann kommen wir wieder zum Auto zurück, da sagen wir Mädchen halt ja ok, ist schon gut, aber...

(Laughs), well, let's come back to the cars, there we girls say, right, it's okay, but...

7. Albert: Ist das vom Wesen der Mädchen her so oder ist das einfach eher Kultur?

Is that essential for girls or more cultural?

8. Seraina: Knaben sind etwas bequemer. Wenn wir Frauen irgendwo den Bus nehmen, dann sitzt ein Mann gerade ins Auto.

Boys are a bit lazier. When we as women take a bus, men just sit in a car.

When Mara speaks about the attitude of men and women towards environment, she draws on the folk psychology repertoire. The folk psychology repertoire is used to construct innate or instinctive knowledge, common sense, and individual or shared convictions about other persons. In this discourse it helps Mara to construct shared conviction that girls are more interested in environmental issues. In her talk, it is also commonsense that men are more into cars than women. This gender construction is in fact something that can be seen everywhere in Switzerland, in TV advertisements, in newspapers and journals, and on signs along roads. In fact, when Philipp in the initial statement admits that he would prefer to drive around with his car, he takes part in claiming the action by drawing on the folk psychology repertoire. The reaction of Mara shows that she takes his male identification with car driving for granted and also knows how women normally react in this situation. It is remarkable how she extends her considerations from young women to all women (turn 6), changing without further comment from "girls" to women. Seraina (turn 8) draws on the folk psychology repertoire to give a reason for men's behavior: men are lazier than women. This is so by nature, as it evidently does not require further explanation. Therefore, it is only reasonable to use "women" instead of "girls," because for her (and, as she presupposes, also for the interviewer) it is a bit of information about every female, independent from her age, a pendant to the absolute Truth of scientific facts. Notice that Albert tries to break the rules of the folk psychology repertoire by bringing "culture" into consideration (turn 5). Again this is an opportunity to see how a discourse repertoire works. In her answer, Seraina does not even allude to Albert's question. The term "cultural" has no resonance in the setting of the folk psychology repertoire. Instead the young woman reacts by providing one more (folk psychological) stereotype about men: men are lazier than women. There is actually another instance in which the folk psychology repertoire is mobilized in this fragment, one that we already came across: "environmental protection" means "less car driving." This demonstrates how elements of a repertoire, here the folk psychology repertoire, can be found across all the interviews of our project. These really function like atoms from which the various argumentations in different contexts may be built. 
Across our interview set, students make a clear distinction between men and women when it comes to the environment. Women are considered to be clearly more environmentally friendly. The students attest this to girls more than to boys, but also to mothers more than to fathers (who often are depicted as indifferent to these matters). The same difference holds for brothers and sisters. Both boys and girls supported this concept throughout the in-depth interviews. In their talk, women appear as naturally tending to be nursing and caring towards the environment-an environment that will be the reality of the next generation.

There is an interesting link, however, between the two uses of the folk psychology repertoire (i.e., "women are more environmentally friendly" and "environmental protection means less car driving"). Most of the students intuitively reduce environmental protection to correct litter disposal and the use of public transports. Since women and girls are considered to be less interested in vehicles than men and boys, and since the students articulate girls and women to be more tidy and neat than men and boys, the conclusion is easily drawn that women and girls are more ready for environmental protection than men and boys. This is mainly a result of discursively combining two "atoms" of the folk psychology repertoire.

There is another "atom" of this repertoire that plays an important role. In the wholeclass sessions and in the in-depth interviews, students often linked environmental questions to political attitudes. Thereby they only roughly distinguished between left- and right-wing positions and they did not tie them to the national political landscape or to certain political parties. In the mobilization of folk psychology repertoires, left- and right-wing positions have much to do with racism and negative attitudes towards immigration and immigrants. One class in particular - from the rural part of the region - was heavily divided into openly racist and decisively non-racist discourse. By drawing on the folk psychology repertoire, boys were described (and described themselves) as mostly racist, whereas girls mostly favored the integration of immigrants. All students across classes agreed that left-wing people care for the environment while right-wing people do not. They also agreed in the explanation: a left-wing attitude is described as generally caring, thoughtful, and engaged in the variety of life and in the peaceful living together. Right-wing individuals are described as selfish, straight forward in their search for success, and merciless in their competitiveness. The students referred to these descriptions as "by nature." There was no need to discuss them further.

These three elements of the folk psychology repertoire identified here are consistent with each other and mutually endorse one another. If women are more left wing and if leftwing people care more for the environment, then this is consistent with the idea that women "by nature" care more for the environment. If men are more into cars and more right wing, and right-wing people care less about the environment, then these two male aspects are also consistent. This shows how a repertoire, here the folk psychology repertoire, provides building blocks to coherently construct life world meanings.

Articulating a future (of the) world

The graph of Sorgenbarometer 2007 most recently shows an increase of environmental protection concerns to $25 \%$ in 2007 . Another survey in $2008^{5}$ reports that in $2007,31 \%$ of Swiss answered that global warming is their most or second most important concern.

\footnotetext{
5 http://www2.acnielsen.com/reports/index.shtml. A regular syndicated online consumer survey across multiple countries about the attitudes and opinions of consumers worldwide. Consumer Confidence is
} 
Amongst nations, only the French (34\%) are even more concerned about this issue. Concerns about the environment do experience a revival, and global warming is becoming the new label in the coverage of severe environmental problems. Of course this topic recently has been very prominently featured in the media. An important force mediating this change was Al Gore's documentary "An Inconvenient Truth," which served to raise public consciousness and conscience about issues of the environment and environmental protection. At the time when we interviewed the middle school students, the topic was not yet so outstanding in the media (though in Switzerland it had been acute because of the inundations mentioned). It therefore does not astonish that students talked about global warming as an emblem of a fatal future-to-come. Consider the following interview fragment.

1. Albert: Siehst du das kritisch, wie das weitergeht mit der Zukunft?

Are you skeptical in foreseeing what the future holds for us?

2. Martin: Also nicht wirklich für mich, oder wenn ich einmal Kinder habe, aber irgendeinmal wird das passieren. Dann werden alle mit Sonnencreme herumlaufen mit Sonnenschutzfaktor 100 oder so, weil sie sich sonst an der Sonne verbrennen. Das Klima erwärmt sich ja immer, und wir waren einmal an einer Ausstellung, wo gezeigt wurde, wie es sein wird, wenn das ganze Polareis abschmilzt: da schauten nur noch der Pilatus und der Bürgenstock aus dem Wasser. Sonst alles weg.

[i] Well, not really for me, or when I'll have children, [ii] but sometime it'll happen. [iii] Then everyone will be walking around with a sun cream of kind of protection factor 100, because otherwise people would burn in the sun. [iv] The climate is constantly warming up, right, [v] and we once were at an exhibition where they showed us what happens when the whole polar ice is melted off: [vi] only the mountain Pilatus and Bürgenstock can be seen above the water surface [vii] Everything else has gone.

3. Albert: Machen dir solche Szenarien Angst?

[viii] Are you scared by such scenarios?

4. Martin: Also mir nicht, weil es wird mich nicht betreffen. Aber ich nehme an, das wird kommen. Nicht umsonst werden Planeten gesucht, wo die Menschheit fähig sein würde, zu überleben.

Well, not I personally, because it will not concern myself. [ix] However, I suppose this will happen. [x] Not in vain do they search for planets where humans could survive.

When Albert asks Martin whether he is skeptical in foreseeing the future, then Martin answers first that he is not scared as to his own future and the future of his children (turn 2: [i]). But in the same phrase he asserts that "it" surely will happen at some time (turn 2: [ii]). "It" is something that will happen in the fare future, and this is for sure. Martin does not articulate skeptical views about his own future or the future of his children, because "it" will happen much later, after their lifetime. What is "it"? In (turn 2) Martin describes "it" as dangerous sunburn. The sun will burn so much that people will have to walk around with a sun cream "of protection factor 100" (turn 2: [iii]). The second aspect of "it" is, in Martin's words, that the climate constantly gets warmer. This is something that will not only happen in the far future, but it is so already ("The climate is constantly warming up..." (turn 2: [iv]). In Swiss German, the phrase "Das Klima erwärmt sich ja immer"

Footnote 5 continued

measured twice a year across more than 30 countries, along with other timely social, economic and political issues. 
includes the dimension that the climate warms up at this instant and that this trend will continue into the future. In the next phrase, Martin describes what he has seen in an exhibition (turn 2: [v]): when the polar ice melts off, then only the Pilatus and Bürgenstock mountains can be seen above the water surface [vi]. These two mountains are the highest ones in the region where he lives. So Martin describes a situation, wherein the whole region around Lucerne is flooded, and, consequently, only the two highest points of the region, the top of the mountains Bürgenstock and Pilatus are above water level (turn 2: [vi]). "Everything else has gone" (turn 2: [vii]). The argument realized is this: when the climate warms up, then the polar ice starts melting, and if all the polar ice melts there will be so much more additional free water. The region of Lucerne (where he lives) will be flooded to a degree and only the most exposed two mountain peaks will be above water level. All in all, the "it" (the bad situation), which will happen after Martin's and his children's lifetime, is described by a dangerously burning sun and a warming of the climate that will cause a flooding of the whole region.

When Albert once again asks Martin if he is scared about "these scenarios" (turn 3: [viii]), the latter repeats that "no," because he himself will not be affected. But, again, he assures that "I suppose this will happen" (turn 4: [ix]). He says that "they search for planets, where humans could survive" (turn 4: [x]). In German, "Sie suchen" is a muchused expression to talk about scientists. Martin talks about scientists, who search for other planets. They do this, as he points out "not in vain." They have a purpose. They do it to give humans a chance to survive, when "it" comes. All in all, Martin repeats that he is not scared because it will not affect himself. However, he argues that this does not mean that the future to come is not scary. It is so scary that scientists search for other planets where humans will be able to survive, when the sun scorches the earth and living areas will be flooded.

In this fragment, Martin repeatedly draws on the folk science repertoire. In using the folk science repertoire, he and his peers draw on observations that can be made in the everyday world, seen on television, or on topics that they know from science courses. The results of these observations are taken to be facts, taking a stance close to scientism. It is a fact, first and foremost, that "it" will happen, although not during Martin or his children's lifetime. He describes what "it" will be by providing observations. One putative observation is that the sun will burn to such a degree that one has to protect oneself using an extremely powerful sun cream (sun protection factor 100). He could have drawn this observation from the media, where information about the growing danger of sunburn is constantly provided. Also in TV advertisements sun cream products with high protection factors are regularly promoted. Sunburn is something that everybody knows about and everybody experiences when s/he does not protect against the sun.

The second observation that describes "it," is the warming of the climate. This issue can frequently be seen, heard, and read in the media. For many or most Swiss people, global warming is an undisputed fact, so that mentioning or referring to it is (nearly) undisputable. This fact therefore belongs to the folk science repertoire. Global warming as a Truth has also been discussed in Martin's science class (as the teacher confirmed). Immediately after having invoked the warming of the climate, Martin refers to an exposition visit where there was display concerning the melting of the polar ice. Here, warming and melting are evoked "in the same breath." This observation corresponds to commonsense "folk physics," whereby ice melts when exposed to heat. Martin talks about the consequence of melting the polar ice cap ("they showed us what happens when..."): the whole region where he lives will be flooded so that only two salient mountains 
("Bürgenstock," "Pilatus") would be visible above the water surface, thus combining an absolute scientific Truth and folk physical knowledge to a "true" picture of the ecological future. He also combines this picture with a personal observation. He had made this observation in an exhibition ([v]), where he might have been with his class. The science teacher of the class told us that he frequently takes his students to exhibitions. There is, for example, a museum in Lucerne (a town in the region) called "Gletschergarten" (garden of the glaciers), which is specialized on issues of glaciers and remains of ice ages and shows a permanent exhibition on global warming. The "Gletschergarten" is a popular destination for regional school students. A last observation is that scientists search for other planets where humans can survive. This can also be seen in the media and it is also the concern of many science fiction films.

All in all, Martin draws on the folk science repertoire by conveying "facts" from a variety of different sources: from the media (sunburn), from the class room (warming of the climate), from physical folk knowledge (ice melts when it gets warmer), from an exhibition which he had visited during a school excursion, and from broadcasts about science issues, respectively, science fiction films. These observations are taken to be facts, meaning "real" things, events, or occurrences that really and undeniably occur and therefore constitute absolute Truth. In Martin's discourse, "it," described by this variety of observations, constitutes an undisputable Truth, known by authentic testimony in the media, in school, in an exhibition. This undisputable Truth depicts a bleak, scary future for the environment. Because they are true in this strict sense of authentic testimony, this future is inevitable. The only reason why Martin is not scared is because this future is so far away that he and his children will not have to deal with it during their lifetimes.

Most students express real pessimism concerning the environmental future of our world. The students describe the environmental future in terms of a silently progressing destruction of nature, of global warming, and of inevitable natural cataclysms. The information sources of these catastrophic scenarios are science classes and the media. The students, however, reproach neither the teacher nor the media of exaggerating. They judge them to be only messengers of a sad reality, and the way they present this diagnosis in a calm manner itself is scary. Students often raised the question, whether they will be victims of environmental catastrophes in the future or not. The great majority decided that not, simply because the scenario would evolve too slowly. They even express doubt that their children would experience it. Most of them suggest that only their grandchildren will be confronted with the first signs of future apocalypse. This explains why the students appear so calm and why many of them confirm that they rather seldom are concerned with environmental anxiety. When they are, the reason for it is mainly bad environmental news in the media.

In sum, students' emotions concerning global environment are pessimistic and disenchanted. Environmental fears, however, if they are relevant at all, hide below a calm surface. One reason for this calmness surely is that they consider their own future as safe, because environmental change is a slow process. In the 1960s, students actively dreamed of a different world envisioned sometimes as something heaven-like-flower power and peace in California - or as the result of a radical revolution toward communism (a position typical for many student movements in Europe). It is of note that most of the students in the present study did not articulate how an ecological world would look like. If somebody alluded to concepts such as "less technology" or "more nature," it was not without asserting that changes like this should of course not compromise a consumption-oriented life style. Consequently and by drawing on the pragmatist repertoire, the students argue 
that these are not realistic options. The discourse is marked by a deep-reaching scepticism towards comprehensive visions and an unquestioned commitment to consumerism. Any credited draft for the future had to guarantee materialistic desires and to respect comprehensive hedonism. Otherwise it was called "unrealistic" or "illusionary." In our database, societal concepts of the future world always draw on the pragmatist repertoire.

\section{Interpretive repertoires: resources for students and teachers}

In this study we analyze the discourse of 15- to 16-year-old Central Swiss junior high school students about environment and environmental protection. The topic is salient because in Central Switzerland the science curriculum for lower-secondary classes demands of science teachers ambitious goals involving the sensitisation of their students towards ecological issues. In considering the implications of our work, a discourse analytical approach to the students' environmental discourse is important because it provides the means to understand their environmental culture as a microcosm nested in the (Swiss) environmental culture. Teaching environmental issues in science education is thus seen as a cultural process more than as a transfer of environmental knowledge.

Consequently, our analysis proceeded by means of interpretive repertoires, which function as building blocks of societal discourse that speakers can mobilize in concrete talk about pertinent issues. Although we mentioned the influence of practical aspects of the curriculum on the school culture (Fig. 2), this was only to provide the cultural-historical background. Since the repertoires did not reflect this curricular aspect (and we did not expect it, because our repertoires proved to be societal on a "large scale"), we did not focus on them during our analysis. This is not to say that practical curricular aspects had no influence on our students. However, discourse analysis in our theoretical framework abstains from any temptation to "look into the heads of the talkers". No talk, no analysis.

In the talk of our students about environmental issues, our analysis reveals the emergence of two core repertoires, each splitting into two-second-order repertoires. The analysis of the transcripts shows that the Swiss environmental discourse-as realized in junior high school students' talk-rides on the mobilization of these two/four repertoires. We consider the commonsense and the agential repertoire to be the two core repertoires. The commonsense repertoire splits up into the folk science repertoire (emerging from the dialectical melthings tension) and the folk psychology repertoire (emerging from the melyou tension). The agential repertoire also splits up in two areas of tension to give rise to two additional, second-order repertoires. The first repertoire emerges from the tension between the ideal and real. We called it the pragmatist repertoire. The second repertoire arises from the tension between self and others. This repertoire was denoted by the term control repertoire.

Based on these two/four interpretive repertoires we present an analysis of the most salient topics concerning the environment and environmental protection that unfolded in three class discussions and in 12 in-depth interviews conducted with students from the classes. Seven core topics have been found. These issues-in the order of presentationinclude (a) consumerism, economical grown, and globalization as causes of environmental degradation; (b) the importance of environmental protection; (c) the role of personal agency in a world populated with others who may not act likewise; (d) the search for solutions in technological progress rather than fundamental changes of attitude towards environmental issues; (e) the role of NGOs, such as Greenpeace and WWF in bringing about changes; (f) the differences between men and women when it comes to talking about 
and acting toward the environment; and (g) students' visions of and for a future (of the) world.

Our results are highly relevant to science education in Central Switzerland. As described in the introduction, the curriculum in this part of the country outlines that students will (a) acquire insight into environmental issues, (b) form personal positions on environmental topics, (c) become involved in local, national, and global environmental problems, (d) be ready to conserve the natural environment, (e) consume and live in an environmentally friendly manner, and (f) respect the environment during leisure and sports time. If we had stopped with the results of the survey conducted by our pre-service teachers, we might have come to the conclusion that this middle-school students, who had already completed the curriculum, had indeed been sensitized to environmental issues in the way the curriculum prescribes. The class and in-depth interviews, however, relativize this conclusion and raise questions as to success of the instruction preceding our research. How serious are these questions?

Again at face value, the talk of our students might have been deemed discouraging - the result of a huge pedagogical failure of the current environmental curriculum that all participants had completed at the time of the study. However, before drawing rash conclusions, we should recall the assumptions of discourse analysis. The interpretation of our students' discourse in terms of the four interpretive repertoires does not claim to hold hand on a transparent representation of the students' "genuine" individual's attitudes and beliefs or the true nature of any described events. Rather, our framework allows us to understand the interplay between the different repertoires leading to the emergence of a new understanding of the students' various arguments, shedding a new light on their belief and attitude talk.

One of the most important aspects of this new understanding is that our analysis shows how our students' discourse is locked into a framework of "facts" fixed by the commonsense repertoire. The folk science repertoire fixes "facts" of the physical world as intrinsic, unchangeable, and indisputable. The folk psychology repertoire fixes "facts" of the mental world in the same way. People who are locked in this discourse come to be stuck in a world full of unchangeable "facts" that confine their room to maneuver (agency). This confinement is the interface for the unfolding of the agential repertoire into its two variations, because it creates the dialectical tensions of ideallreal and of selflother. These ways of unfolding give rise to the pragmatist and control repertoires. The pragmatist repertoire takes the outer "facts," provided by the folk science repertoire as a starting point to distinguish between "ideal" concepts of ecologism, on the one hand, and values and "real" concerns of the factual world, on the other hand. It then favors the materialization of agency respecting the constraints of outer "facts," deriving from science, technology, and other fields of expertise. The control repertoire expresses a personal helplessness in face of an anonymous mass of "others" interpreted by the folk psychology repertoire and consequently delegates agency to impersonal, institutional forces like innovation, growth, and progress.

By their nature, interpretive repertoires generally are unchallenged and unchallengeable ways of talking - if ways of talking are challenged, they do not belong to or constitute, by definition, an interpretive repertoire. Students reject those who do challenge interpretive repertoires-including ecological activists and NGOs-and who do try to overcome "factual" constraints and to consider a new world as illusory, insensible, annoying, and even irresponsible. Students greet with irony and sometimes even with disgust and anger the breaking of the rules embodied by the interpretive repertoires. 
The new light that our discursive analysis sheds on our students' talk may be described in this way: This talk does not-as it could be seen on face value-convey an active orientation toward materialism and hedonism, and it does not commit treason to the ideals of a green culture. It is first and foremost a reaction to a lost locus of self-control in a "fact"-oriented physical and mental outer world. This discursive loss of control leads to an articulation of personal agency in a rigid pragmatism, accounted for by the four interpretive repertoires that underpin current societal discourses about environment and environmental protection.

What do these results mean for reconfiguring the way in which we might teach about the environment and environmental protection? Because interpretive repertoires are characteristic of culture and language, there is no sense in trying to eradicate them through instruction. Rather, similar to Roth and Lucas (1997), we suggest interpreting the curriculum guidelines in a way that it allows students to expand their existing repertoires. That is, we do not recommend changing the positions students take, which would be a form of brainwashing, but to increase their resources for underpinning whichever stance they take on whatever issue. Because in Switzerland, teachers have considerable freedom with respect to the implementation of curriculum guidelines, a useful intervention would consist of helping future science teachers understand how they can assist students in such an expansion of their repertoires. For example, the teachers could introduce activities so that students can reason about nature and the behavior of others in ways that expand the commonsense repertoire. In the same way, teachers could introduce activities that allow students to expand the agency repertoire beyond the simple dichotomies confronting the ideal and real (pragmatist repertoire), on the one hand, and me and "the others" (control repertoire), on the other hand.

\section{References}

Bakhtin, M. M. (1993). Toward a philosophy of the act. Austin: University of Texas Press.

Baron-Cohen, S., Wheelwright, S., Stone, V., \& Rutherford, M. (1999). A mathematician, a physicist and a computer scientist with Asperger syndrome: Performance on folk psychology and folk physics tests. Neurocase, 5, 475-483. doi:10.1080/13554799908402743.

Bundesamt für Umwelt, Bundesamt für Statistik (BAFU, BFS). (2007). Umwelt Schweiz 2007. Bern/Neuchâtel: Bundesamt für Umwelt, Bundesamt für Statistik (BAFU, BFS).

Cobern, W., \& Loving, C. C. (2007). An essay for educators: Epistemological realism really is common sense. Science \& Education, 17, 425-447. doi:10.1007/s11191-007-9095-5.

Credit Suisse (2008). Sorgenbarometer. Retrieved September 25, 2008 from http://emagazine.credit-suisse. com/app/topic/index.cfm?fuseaction=OpenTopic\&coid=165\&lang=DE.

Edwards, D., \& Potter, J. (1992). Discursive psychology. London: Sage.

Gilbert, G. N., \& Mulkay, M. (1984). Opening Pandora's box: A sociological analysis of scientists' discourse. Cambridge: Cambridge University Press.

Hirschfeld, L. A., \& Gelman, S. A. (1994). Mapping the mind: Domain specificity in cognition and culture. New York: Cambridge University Press.

Holstein, J. A., \& Gubrium, J. F. (2005). Interpretive practice and social action. In K. D. Denzin \& Y. S. Lincoln (Eds.), The Sage handbook of qualitative research (pp. 484-505). Thousand Oaks: Sage.

Hsu, P.-L., Marshall, A., Roth, W.-M., \& Guenette, F. (2009). To be or not to be? Discursive resources of (dis)identifying with science-related careers. Journal of Research in Science Teaching.

Hsu, P.-L., \& Roth, W.-M. (2009). Conceptions, attitudes, beliefs, and identity from the perspective of discursive psychology. In B. J. Fraser, K. Tobin, \& C. McRobbie (Eds.), Second international handbook of science education. Dordrecht: Springer.

Innerschweizer Erziehungsdirektorenkonferenz (iEDK). (1997). Lehrplan Naturlehre. Ebikon: Zentralschweizerischer Beratungsdienst für Schulfragen. 
McKenzie, P. J. (2003). Interpretative repertoires. Retrieved April 28, 2009 from The University of Western Ontario Web site: http://publish.uwo.ca/ pmckenzi/McKenzie.pdf.

Potter, J., \& Wetherell, M. (1987). Discourse and social psychology: Beyond attitudes and behaviour. London: Sage.

Potter, J., \& Wetherell, M. (1988). Discourse analysis and the identification of interpretive repertoires. In C. Antaki (Ed.), Analysing everyday explanation: A casebook of methods (pp. 168-183). Newbury Park, CA: Sage.

Ricœur, P. (1992). Oneself as another. Chicago: University of Chicago Press.

Roth, W.-M. (2005). Doing qualitative research: Praxis of method. Rotterdam: Sense.

Roth, W.-M. (2008). The nature of scientific conceptions: A discursive psychological perspective. Educational Research Review, 3, 30-50. doi:10.1016/j.edurev.2007.10.002.

Roth, W.-M., Lee, Y. J., \& Hwang, S.-W. (2008). Culturing conceptions: From first principles. Cultural Studies of Science Education, 3, 231-261. doi:10.1007/s11422-008-9092-2.

Roth, W.-M., \& Lucas, K. B. (1997). From "truth" to "invented reality": A discourse analysis of high school physics students' talk about scientific knowledge. Journal of Research in Science Teaching, 34, 145-179. doi:10.1002/(SICI)1098-2736(199702)34:2<145::AID-TEA4>3.0.CO;2-T.

Sewell, W. H. (1992). A theory of structure: Duality, agency and transformation. American Journal of Sociology, 98, 1-29. doi:10.1086/229967.

Simonneaux, L., \& Simonneaux, J. (2009). Students' socio-scientific reasoning on controversies from the viewpoint of education for sustainable development. Cultural Studies of Science Education. doi: 10.1007/s11422-008-9141-X.

Vološinov, V. N. (1973). Marxism and the philosophy of language. Cambridge: Harvard University Press. Vygotsky, L. S. (1986). Thought and language. Cambridge, MA: MIT.

\begin{abstract}
Albert Zeyer worked as a mathematics and science teacher, a medical doctor, and as a teacher educator. He currently is a senior lecturer in science education at the University of Zurich, at the Swiss Federal Institute of Technology Zurich (ETH), and at the University of Teacher Education Central Switzerland. His research interests in science education include health and environment, cultural border crossing, and applied ethics. His recent articles include “A Beginners' Module of Integrated Natural Science for Secondary Teacher Students. The Result of an Educational Reconstruction Process over Three Iterations" (Springer, together with Manuela Welzel), and "Public Reason and Teaching Science in a Multicultural World" (Science \& Education).
\end{abstract}

Wolff-Michael Roth is Lansdowne Professor of Applied Cognitive Science at the University of Victoria, Canada. He studies knowing and learning in mathematics and science across the life span from an interdisciplinary perspective that combines cognitive anthropology, linguistics, and cultural-historical activity theory. His recent articles includes "Radical Uncertainty in Scientific Discovery Work" (Science, Technology, \& Human Values) and "The Emergence of 3D Geometry from Children's (Teacher-Guided) Classification Tasks" (The Journal of the Learning Sciences) and the edited volume "Generalizing from Educational Research" (Routledge 2009, with K. Ercikan). 